Portland State University

PDXScholar

6-1-2021

\title{
The Spatial and Temporal Evolution of the Portland and Tualatin Forearc Basins, Oregon, USA
}

\author{
Darby P. Scanlon \\ Portland State University \\ John Bershaw \\ Portland State University, bershaw@pdx.edu \\ Ray E. Wells \\ Portland State University, rwells@pdx.edu \\ Ashley R. Streig \\ Portland State University, streig@pdx.edu
}

Follow this and additional works at: https://pdxscholar.library.pdx.edu/geology_fac

Part of the Geology Commons

Let us know how access to this document benefits you.

Citation Details

Scanlon, D. P., Bershaw, J., Wells, R. E., \& Streig, A. R. (2021). The spatial and temporal evolution of the Portland and Tualatin forearc basins, Oregon, USA. Geosphere, 17(3), 804-823. https://doi.org/10.1130/ ges02298.1

This Article is brought to you for free and open access. It has been accepted for inclusion in Geology Faculty Publications and Presentations by an authorized administrator of PDXScholar. Please contact us if we can make this document more accessible: pdxscholar@pdx.edu. 


\section{GEOSPHERE}

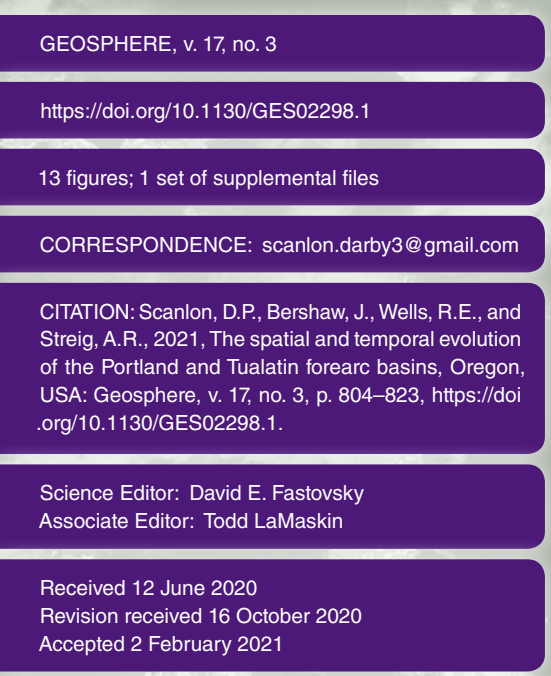

Accepted 2 February 2021

\section{Published online 21 April 2021}

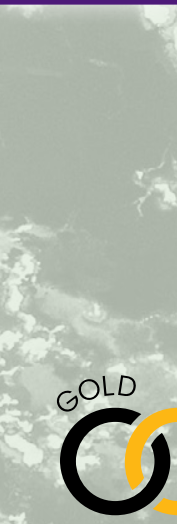

OPEN ACCESS

THE GEOLOGICAL SOCIETY OF AMERICA ${ }^{\circledR}$

forearc is deforming the basins and producing local earthquakes beneath the metropolitan area.

The Portland and Tualatin basins are part of the Salish-Puget-Willamette Lowland, a 900-km-long forearc depression lying between the volcanic arc and the Coast Ranges of the Cascadia convergent margin. Such inland seaways are characteristic of warm, young slab subduction. We analyzed the basins to better understand their evolution and relation to Coast Range history and to provide an improved tectonic framework for the Portland metropolitan area. We model three key horizons in the basins: (1) the top of the Columbia River Basalt Group (CRBG), (2) the bottom of the CRBG, and (3) the top of Eocene basement. Isochore maps constrain basin depocenters during (1) Pleistocene to mid-Miocene time (0-15 Ma), (2) CRBG (15.5 16.5 Ma), and (3) early Miocene to late Eocene (ca. 17-35 Ma) time. Results show that the Portland and Tualatin basins have distinct mid-Miocene to Quaternary depocenters but were one continuous basin from the Eocene until mid-Miocene time. A NW-striking gravity low coincident with the NW-striking, fault-bounded Portland Hills anticline is interpreted as an older graben coincident with observed thickening of CRBG flows and underlying sedimentary rocks. Neogene transpression in the forearc structurally inverted the Sylvan-Oatfield and Portland Hills normal faults as high-angle dextral-reverse faults, separating the Portland and Tualatin basins. An eastward shift of the forearc basin depocenter and ten-fold decrease in accommodation space provide temporal constraints on the emergence of the Coast Range to the west. Clockwise rotation and northward transport of the

Darby Scanlon (D) https://orcid.org/0000-0002-0564-2438

\section{INTRODUCTION}

The Portland and Tualatin basins are part of the Salish-Puget-Willamette Lowland, a forearc trough along the Cascadia subduction zone that is formed by oblique convergence of the Juan de Fuca plate beneath North America (Fig. 1; Evarts et al., 2009). The inland Salish-Puget-Willamette Lowland trough is separated from offshore basins by the Coast Range, and in that respect, it is similar to the Nankai margin of southwest Japan, southern Alaska, and southern Chile (Bassett and Watts, 2015). Such inland seas and lowlands are population centers, and they are tectonically active, producing, for example, the upper-plate 1995 M 6.9 Kobe earthquake in southwest Japan and Cascadia's M 7+ Seattle earthquake ca. 900 A.D., and in the lower plate, Cascadia's 2001 M 6.8 Nisqually earthquake and the $2019 \mathrm{M} 7$ Anchorage earthquake (Wald, 1996; Kao et al., 2008; Nelson et al., 2014; West et al., 2020).

Rogers (2002) suggested that these margins with inland seas were the product of young, warm slab subduction, and more recently, Bodmer et al. (2019) have correlated Cascadia's Coast Range elevation with buoyant asthenosphere along strike. The Coast Range appears to be primarily a late Neogene feature, as flood basalts of the Colum bia River Basalt Group (CRBG) sourced from the backarc flowed across the forearc into the ocean across a broad front from the central Oregon coast to the central Washington coast between 16 and $12 \mathrm{Ma}$ (Snavely et al., 1973; Beeson et al., 1979).
The uplift of the Coast Range may be superimposed on or partly coincident with a Neogene forearc transition from Paleogene transtension and mafic magmatism to deformation dominated by northsouth transpression due to impingement of the northward-migrating forearc against the Canadian Coast Mountains (Snavely and Wagner, 1963; Snavely et al., 1993; Snavely and Wells, 1996; Wells et al., 1998; McCaffrey et al., 2013; McPhee et al. 2014; Wells et al., 2014).

The record of Oregon Coast Range development, forearc migration, and Cascade magmatism as recorded in the stratigraphy of the Portland and Tualatin basins is poorly understood. In this study, we provide constraints on the structural and tectonic evolution of the Cascadia forearc by tracking basin depocenters (areas of maximum sediment accumulation) in the Portland and Tualatin basins through space and time (e.g., Ingersoll, 1978; Zak and Freund, 1981; Heller et al., 1988; Flemings and Jordan, 1990). Previous geological and geophysical studies have been conducted in the Tualatin basin (Beeson et al., 1989a; Popowski, 1996; Wilson, 1997, 1998; McPhee et al., 2014) and in part of the Portland basin (Beeson et al., 1989a; Roe and Madin, 2013), though an integrated geologic model of both the Portland and Tualatin basins currently does not exist. We synthesize well log outcrop, seismic, aeromagnetic, and gravity data to better understand stratigraphic architecture and the spatio-temporal evolution of accommodation space within the Portland and Tualatin forearc basins. We then use these observations to provide temporal constraints on the emergence of the Oregon Coast Range and initiation of transpressional deformation within the Portland Metropolitan area. Our basin model also provides information needed for 

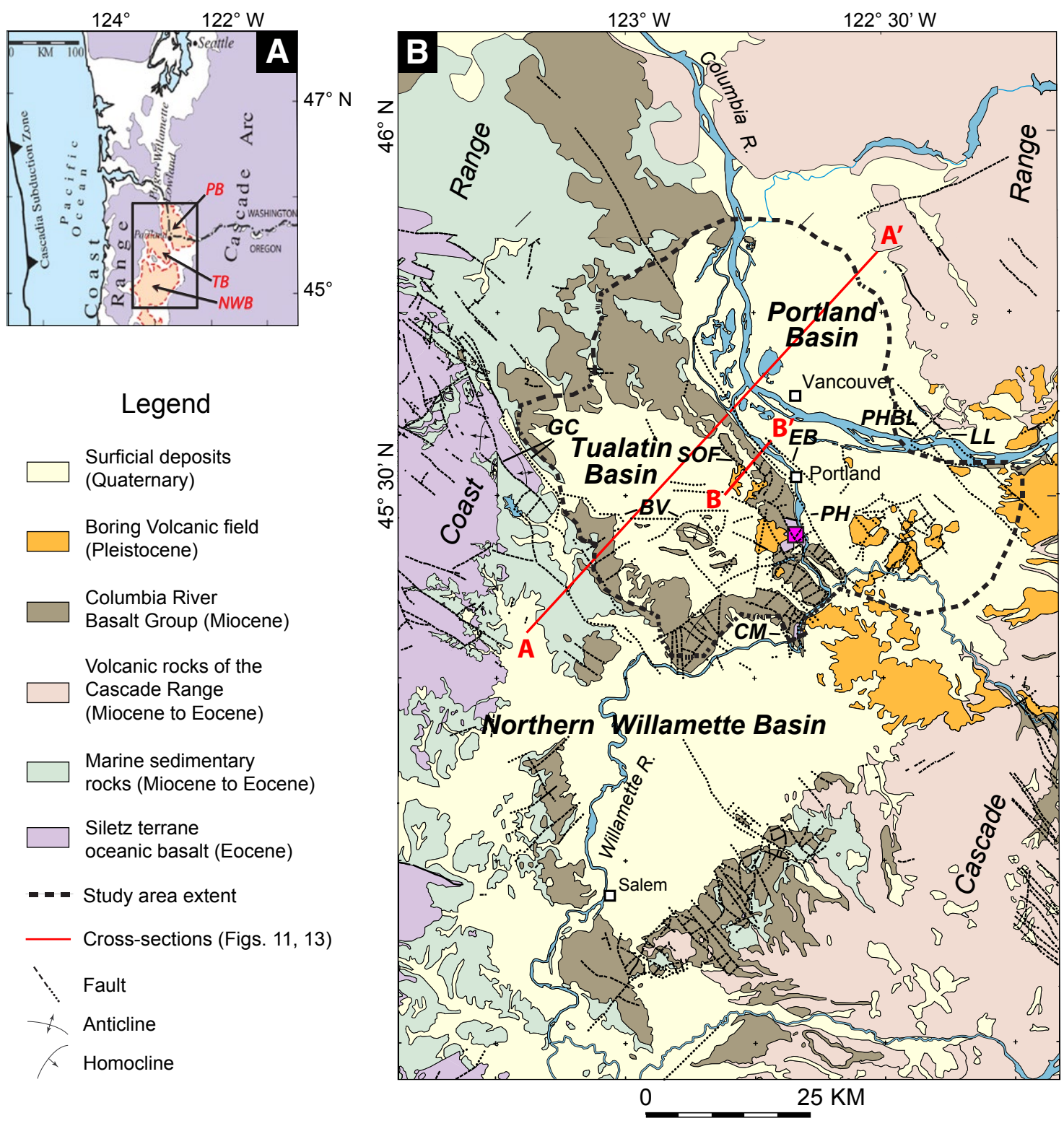

Figure 1. (A) Generalized geology of the

Legend

Surficial deposits

(Quaternary)

Boring Volcanic field

(Pleistocene)

Columbia River

Basalt Group (Miocene)

Volcanic rocks of the

Cascade Range

(Miocene to Eocene)

Marine sedimentary

rocks (Miocene to Eocene)

Siletz terrane

oceanic basalt (Eocene)

- - - Study area extent

_ Cross-sections (Figs. 11, 13)

$\because$ Fault

1 Anticline

A Homocline 
ongoing seismic hazard and resource assessments in the Portland metropolitan and surrounding areas (e.g., Givler et al., 2009; Roe and Madin, 2013).

\section{Geologic Setting}

The Portland and Tualatin basins cover an area of $\sim 3900 \mathrm{~km}^{2}$ and are part of the $900-\mathrm{km}$-long Salish-Puget-Willamette Lowland, a forearc trough situated between the Coast Range and the Cascade volcanic arc (Fig. 1; Evarts et al., 2009; Bassett and Watts, 2015). The basins are elongated in a NW-SE orientation and are generally bound by northwest-striking dextral strike-slip faults (Beeson et al., 1989a; Blakely et al., 1995, 2000; Wong et al., 2001; Liberty et al., 2003; Evarts et al., 2009; Walsh et al., 2011; Wells et al., 2020a). A dextral sense of motion on these bounding faults is compatible with the modern stress field where the maximum horizontal compressive stress is oriented roughly north-south, essentially $45^{\circ}$ oblique to the north west striking faults (Werner, 1990; Yeats et al., 1991). In Paleogene time, the Tualatin and Portland basins were part of a large, continuous marine basin that stretched from the Portland basin west to the present-day ocean (Evarts et al., 2009).

Two crustal earthquakes of $>$ M 5 have been recorded in or near the Portland and Tualatin basins in the past 60 years. A M 5.2 earthquake occurred in the Portland basin in 1962 (Yelin and Patton 1991), and the 25 March 1993 M 5.7 Scotts Mills earthquake that occurred $\sim 58 \mathrm{~km}$ south of Portland indicates that damaging earthquakes are possible (Thomas et al., 1996; Givler et al., 2009). The Gales Creek fault west of the study area shows evidence for Quaternary activity (Redwine et al., 2017; Horst et al., 2019, 2020; Wells et al., 2020b), as clockwise rotation and northward migration of the Oregon Coast Range results in dextral shear on faults in the study area and across the forearc (Fig. 2) (McCaffrey et al., 2007; Wells et al., 2020b).

The stratigraphy of the Portland and Tualatin basins records a history of volcanism and sedimentation in both fluvial and marine depositional environments (Fig. 3). Oceanic basalts and basaltic sedimentary rocks of the Siletz River Volcanics, commonly referred to as Siletzia, comprise the Eocene basement underlying Cenozoic basin fill of the Portland and Tualatin basins (Snavely et al., 1968; Duncan, 1982; Yeats et al., 1996; Wells et al., 2014). Accretion of the Siletzia terrane to North America (NAM) at the latitude of Oregon occurred between 51 and $49 \mathrm{Ma}$ (Wells et al., 2014). West of the study area along the east flank of the Coast Range anticline, basement rocks exposed are lower Eocene submarine basalt of the Siletz River Volcanics, associated diabase sills, and subaerial basalt of the mid-Eocene Tillamook Volcanics (Wells et al. 1984 [their fig. 1], 2014, 2020a; Trehu et al., 1994; Blakely et al., 2000). The southern part of the Portland Hills anticline separating the Portland and Tualatin basins is underlain by the Eocene basalt of Waverly Heights, best exposed adjacent to the Willamette River near the Waverly Heights area (Fig. 1; Beeson et al., 1989b; Blakely et al., 2004). Waverly Heights basalts are similar to the Tillamook Volcanics and are evidence of Eocene Siletzia basement below (McPhee et al., 2014). Cascade arc volcanism was near its present location by ca. 45-40 Ma, after the accretion of Siletzia and westward migration of the subduction zone (Snavely and Wells, 1996; Schmandt and Humphreys, 2011; Wells et al., 2014). Trehu et al. (1994) suggested that the western Cascades erupted over a well-developed sedimentary basin and that the eastern boundary of Siletzia exists beneath the western Cascades. Paleoaltimetry results from central Oregon support interpretations that the Oregon Cascades were high by Oligocene time (Bershaw et al., 2019). Following the accretion of Siletzia to Oregon, at least $2 \mathrm{~km}$ of marine and marginal-marine sedimentary rocks were deposited in both the Portland and Tualatin basins from Eocene to Oligocene time (Popowski, 1996; McPhee et al., 2014; Wells et al., 2020a). In the Portland basin, deposition of these sediments was coeval with eruptions from an incipient western Cascade volcanic arc and their eastern extent delineates the Paleogene coast (Evarts et al., 2009, 2010). In mid-Miocene time, the Columbia River Basalt Group (CRBG) erupted $210,000 \mathrm{~km}^{3}$ of flood basalt from a series of dike swarms near the present-day junction between Oregon, Washington, and Idaho (Reidel et al., 2013). At 15.5-16.5 Ma, flows of the
Grande Ronde Basalt passed through the Cascade Range via the ancestral Columbia River into the nascent Portland and Tualatin basins (Beeson et al., 1985, 1989a; Beeson and Tolan, 1990). CRBG unconformably overlies volcanic rocks of the older eroded Paleogene and Neogene western Cascades and uplifted marine sedimentary rocks as flows inundated the Portland and Tualatin basins (Beeson et al., 1989a; Liberty, 2002; Wells et al., 2020a).

Late Miocene volcaniclastic rocks of the Rhododendron Formation overlie the CRBG in the southeast portion of the Portland basin on the west flank of the Cascade Range (Trimble, 1963). The lower Sandy River Mudstone was deposited in the basin during the last half of the Miocene (Evarts et al., 2009). This unit is interpreted as lacustrine, consisting of silt and very fine sand (Trimble, 1963). At the end of the Miocene, the Columbia River began to deposit coarse sandstone and conglomerates of the lower Troutdale Formation. Clast composition suggests an extrabasinal source in pre-Cenozoic rocks in eastern Washington and Idaho (Evarts et al., 2009). The upper Sandy River Mudstone was also deposited during this time, suggesting the ancestral Columbia River was a meandering system with low-energy floodplains (Tolan and Beeson, 1984; Evarts et al., 2009). Low-potassium tholeiite (LKT) flows erupted at $3.5 \mathrm{Ma}$ in the Cascade Range to the east, generating hyaloclastite as the LKT flowed into the ancestral Columbia River. This resulted in deposition of a hyaloclastic sandstone member of the Troutdale Formation, deposited as a volcaniclastic alluvial fan in the eastern portion of the Portland basin (Evarts et al., 2009). Unconformably overlying the CRBG in the Tualatin basin are $\sim 450 \mathrm{~m}$ of late Miocene and younger fluvial siltstone, sandstone, mudstone, and the Hillsboro formation of Wilson (1998), deposited under low-energy conditions (Yeats et al., 1996; Wilson, 1997, 1998; McPhee et al., 2014). On the basis of gross lithology and stratigraphic position, Madin (1990) considered these sediments equivalent to the Sandy River Mudstone. However, Wilson (2000) suggests that the Portland and Tualatin basins have been relatively isolated from each other since late Miocene time based on differences in elementa geochemistry plots of silt and clay samples from 
Figure 2. (A) Tectonic setting of the Cascadia convergen margin. Oregon Coast Range block (dark brown) rotating about a pole in the backarc is migrating north at $\sim 8 \mathrm{~mm} /$ yr near Portland (modified from Sherrod et al., 2004). Stable North America schematically illustrated by thumbtack. California's Sierra Nevada - tan; Washington forearc deformation zone-purple; and Yakima Fold Belt-orange; red box shows area of Figure 1. Figure modified from Wells et al. (2020b). (B) Clockwise rotation and northward motion of the forearc from GPS velocity field. Figure modified from McCaffrey et al. (2016)

Neogene nonmarine clastic deposits in both basins The present-day topography of the Portland and Tualatin basins is influenced by underlying structure and geologic events of the past 2.5 m.y. Faults trend NW-SE throughout the study area, influencing stream erosion and the distribution of high topography. The Boring Volcanic Field, consisting of cinder cones and associated lava flows, smal shields, and lava cones, erupted west of the Cascade arc axis during the latest Pliocene (Treasher 1942; Conrey et al., 1996; Evarts et al., 2009, 2010). More recently, late Pleistocene glacial outburst floods (Missoula floods) inundated and scoured the study area, depositing mud, sand, and gravel on the valley floors (Waitt, 1985).

The modern boundaries of the Portland and Tualatin basins were established by mid-Miocene time based on distribution maps of the CRBG and inversion of gravity data (Beeson et al., 1989a Evarts et al., 2009; McPhee et al., 2014). Cross sections based on a gravity survey through a light-rail tunnel (Blakely et al., 2004) in the Portland Hills show step-like anomalies that are consistent with steeply dipping reverse faults bounding the Portland Hills anticline, a structure consisting of CRBG that separates the Portland and Tualatin basins (Fig. 1). The Sylvan-Oatfield and Portland Hills faults comprise part of the larger, northwest-oriented Portland Hills-Clackamas River structura zone described by Beeson et al. $(1985,1989 a)$ and Blakely et al. (1995); this zone has experienced folding and faulting since mid-Miocene time (Beeson et al., 1985; Blakely et al., 2004). South of the Beaverton fault, Cooper Mountain and related subsurface structures are interpreted as E-W-oriented

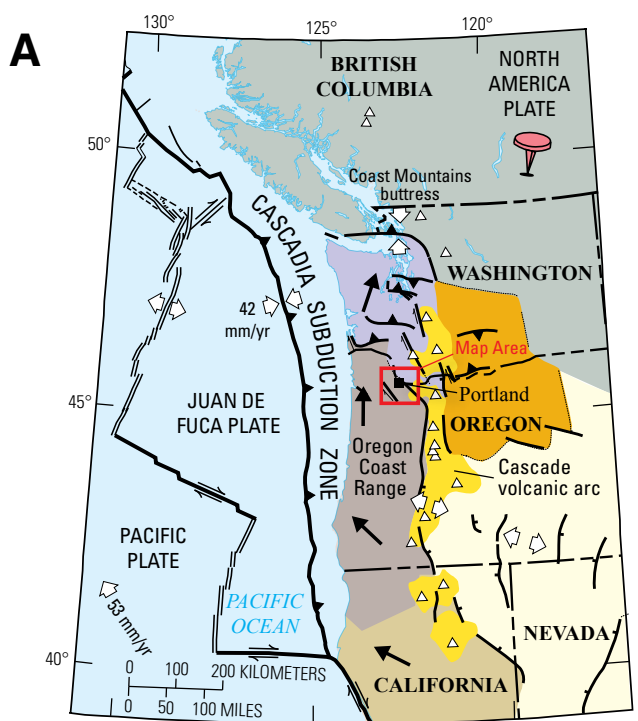

Yakima fold belt Sierra Nevada block

Basin and Range extensional province

$\rightleftharpoons$ Plate boundary fault, arrows show sense of motion

1- Thrust fault, Holocene movement is known or suspected. Sawteeth on upper plate Normal fault, tick on downdropped block

= Juan de Fuca ridge

=:=- Diffuse plate boundary

$\longleftarrow$ Forearc block motion with respect to North America

Relative motion (locally shown in $\mathbf{m m} / \mathbf{y r}$ )

$\triangle$ Quaternary volcano

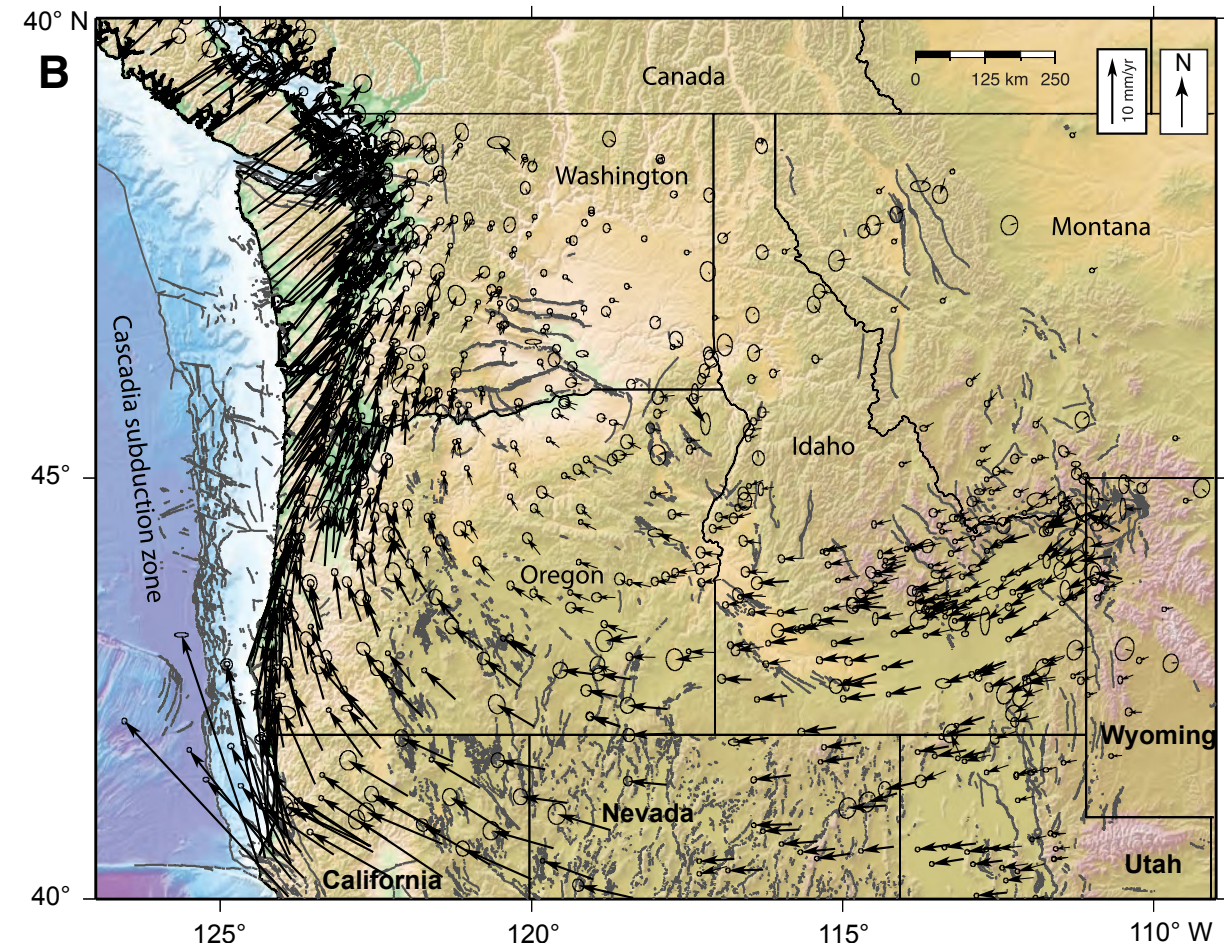




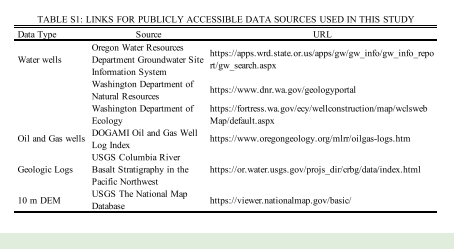

Supplemental Materials. Table S1 contains links to publicly available data sources used in this study. Table S2 contains well names, surface elevations, and stratigraphic picks for surfaces described in the text. Please visit https://doi.org/10.1130/GEOS.S text. Please visit https://doi.org/10.1130/GEOS.S
.13697626 to access the supplemental material, and contact editing @ geosociety.org with any questions. anticlinal folds in CRBG forming the hanging wall of the Beaverton fault (Fig. 5; Wells et al., 2020b). These folds reflect the northward motion of western Oregon in Neogene time.

\section{- METHODOLOGY}

\section{Modeling Geologic Units}

This study models three key stratigraphic horizons in the Portland and Tualatin basins (top CRBG, base CRBG, and Eocene basement) using well-log, outcrop, seismic, aeromagnetic, and gravity data. Model outputs for this study cover $\sim 3885 \mathrm{~km}^{2}$ of the Portland and Tualatin basins. A geologic workflow similar to that in Burns et al. (2011) is employed in which all available data are compiled as inputs for trend surface (horizon) generation. Kingdom Suite, a geological interpretation software package, was used to generate a series of structure and isochore maps, which were converted to metric in Petrosys. Kingdom's Flex Gridding algorithm uses a system of differential equations whose solution yields a grid of points that must pass through (or very close) to the data in $X Y Z$ space, resulting in low residuals. Bicubic interpolation, which uses slope information, was employed to produce smoother output grids. Data used to model stratigraphic surfaces are summarized in Figure 4 and included in Tables S1 and S2

\section{Top CRBG}

A total of 2336 wells were used to model the top of CRBG (Table S2). Many of the wells contained in these data sets do not penetrate the top of CRBG; however, the deepest of these wells provides minimum elevation estimates of CRBG. The best well-log control for the top of CRBG exists at locations along the margin of the basins where top CRBG elevations range from 0 to $250 \mathrm{~m}$ (Fig. 1). In addition to well data, depth-converted seismic profiles in both the Portland and Tualatin basins were used to estimate top CRBG elevations (Popowski, 1996: Wilson, 1997; Liberty, 2002; Ma

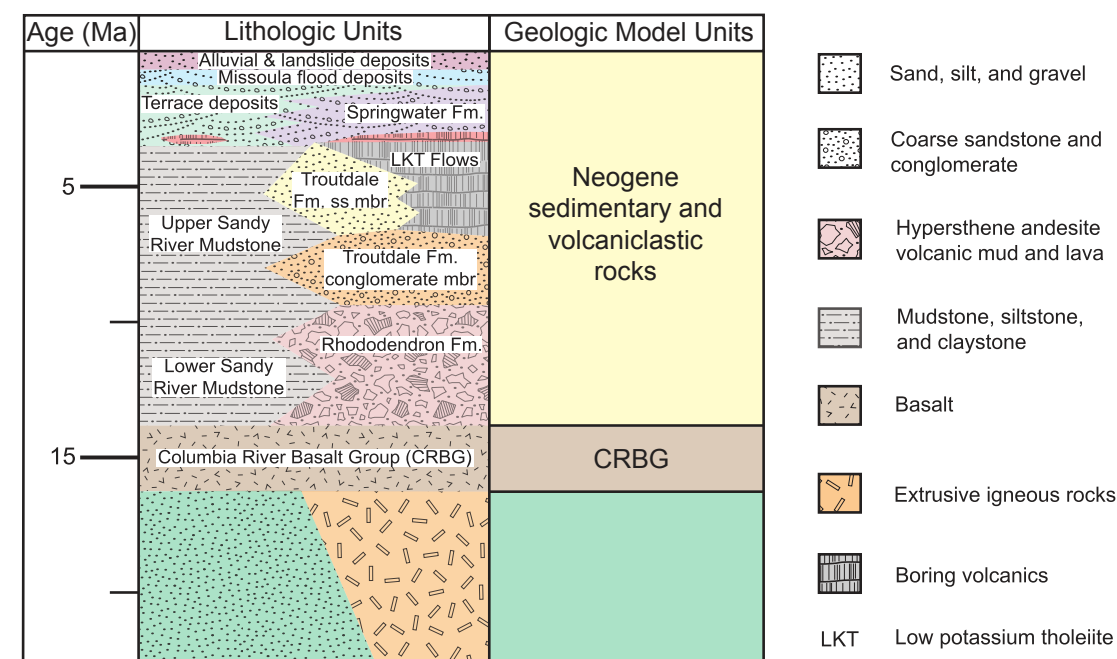

Figure 3. Relationship between mapped geology in the Portland and Tualatin basins and geologic model units of this study. Lithologic units schematically depict their spatial distribution in the study area, with west-southwest to the left and east-northeast to the right. Adapted from Evarts et al. (2009) and Burns et al. (2011). 


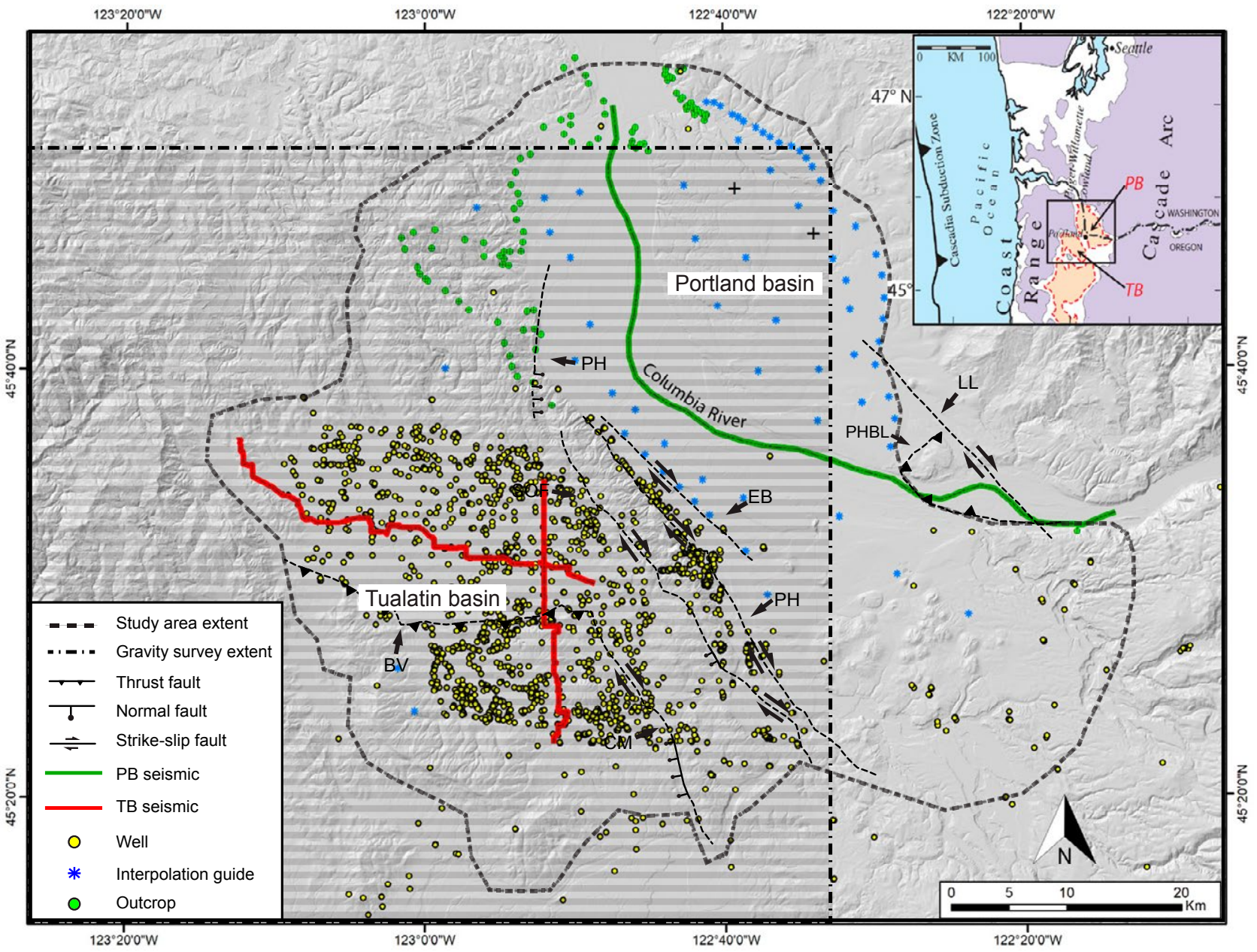

Figure 4. Data control for three interpolated surfaces (Figs. 5-7). Data availability tends to decrease with depth, so that deeper stratigraphic surfaces are not as well constrained. Top Columbia River Basalt Group (CRBG) is constrained by numerous wells and seismic lines. Base CRBG has fewer constraints, and top basement is based on a gravity survey and outcrop data. Dashed faults are inferred. The U.S. Geological Survey CRBG stratigraphy database includes the majority of the deepest wells in the study area (Tables S1 and S2 [text footnote 1]). Interpolation guides (star symbol) prevent surface crossover in areas with sparse data availability. Inset: PB-Portland basin; TB-Tualatin basin. Fault acronyms follow Figure 1. 
et al., 2012). Outcrop data surrounding the basins were integrated using a new, regional geologic map of the study area (Wells et al., 2020a) superimposed onto a 10-m-resolution digital elevation model (DEM). Short-wavelength aeromagnetic anomalies caused by surface and near-surface presence of CRBG and geologic field relations helped qualitatively delineate an interpreted eastern boundary of CRBG in the Portland basin (Fig. 4 ; Blakely et al., 1995, 2000).

\section{Base CRBG}

A total of 52 wells and outcrop exposures from geologic mapping were used to model the base CRBG in this study (Table S2). While only four wells penetrate the entire CRBG section, seven wells reach into the Wapshilla Ridge unit of the CRBG and are interpreted to be close to base CRBG based on stratigraphy (Beeson et al., 1989a). Seismic and well-log data in the Portland basin were used to estimate the thickness of CRBG along a 2D seismic line shot along the Columbia River (Liberty, 2002). The base of CRBG is exposed along the margins of the Tualatin basin and around the Dutch Canyon anticline (Fig. 6). As with the top CRBG horizon surface geology was used to guide interpolation. Previously modeled gravity data were also used to interpret base CRBG elevations, where thinner flows overlie gravity (basement) highs, and thicke flows overlie gravity lows (McPhee et al., 2014). Exposures of pre-CRBG sedimentary rock and basement (i.e., Waverly Heights, southwest flank of the Portland Hills, and Dutch Canyon) provide additional constraints on the thickness and areal extent of this unit in the study area (Fig. 4).

\section{Eocene Basement}

Our Eocene basement surface is derived from the gravity inversion of McPhee et al. (2014). They calculated the depth to the top of the Eocene volcanic basement from the density contrast between the sedimentary basin fill and the oceanic basalt of the Siletz terrane, which is exposed in the Coast
Range and in a few deep hydrocarbon exploration wells. The exposure of Eocene basement at the surface (i.e., Waverly Heights basalt) provides important constraints for both the gravity inversion and geometry of overlying units (Fig. 4; Beeson et al., 1989b). The gravity inversion map is likely inaccurate in the southeast portion of the Portland basin, where modeled basement crosses the overlying top and base CRBG horizons. Sedimentary and volcaniclastic rocks on the eastern margin are largely derived from the Cascade Mountains and are denser than stratigraphically equivalent sedimentary units to the west. McPhee et al. (2014) suggest that Paleogene Cascade volcanic arc rocks underlie parts of the Portland basin.

\section{Modeling Faults}

Major faults in the study area were modeled as sub-vertical planes, based on their linear traces as mapped in Wells et al. (2020a), geophysical data and evidence for strike-slip motion (Fig. 4). Most of the displacement on the northwest-striking and steeply dipping Sylvan-Oatfield, Portland Hills, and East Bank faults is likely dextral (Blakely et al., 1995, $2000,2004)$. Fault surfaces were modeled down to Eocene basement, where offsets in the gravity inversion grid of McPhee et al. (2014) can be correlated to mapped faults at the surface.

\section{Generating Isochore Maps}

Three isochore maps were generated for time intervals that span the basin history: (1) post-CRBG sedimentary and volcaniclastic rocks (0-15 Ma), (2) Miocene Columbia River Basalt Group (CRBG 15.5-16.5 Ma), and (3) early Miocene to late Eocene sedimentary and volcaniclastic rocks (ca. 17-35 Ma) (Fig. 3). Each isochore map is computed as the difference between a geologic unit's top surface and its bottom. As in Burns et al. (2011), interpolation guides were introduced into the modeling process to create surfaces that are consistent with geologic conceptual models and inference from geological and geophysical data (Roe and Madin, 2013).
In addition to well data and geologic mapping, the CRBG isochore map is based partly on Tualatin basin multichannel seismic-reflection data that were collected in 1984-1985 as part of a search for hydrocarbons (red lines in Fig. 4; Popowski, 1996 Wilson, 1997; Oregon Department of Geology and Mineral Industries, 2012). We converted seismic thicknesses from time to meters for this study using a CRBG velocity of $\sim 5300 \mathrm{~m} / \mathrm{s}$ (Spitzer et al., 2008). This time-to-depth conversion produces thickness estimates that are consistent with seismic data in the Tualatin basin correlated to wells (WASH 55816, Cooper Mountain) that penetrate $\sim 305-323 \mathrm{~m}$ of CRBG (Table S2 [footnote 1]).

\section{- RESULTS}

\section{Top CRBG}

The top CRBG horizon is relatively well constrained due to the large amount of subsurface data available (Fig. 4). This surface reveals two distinct relative lows delineating the Portland and Tualatin basins separated by a large northwest-trending anticline associated with the Portland Hills (Fig. 5). The top CRBG horizon reaches a greater depth in the Portland basin with a $-500 \mathrm{~m}$ elevation compared to that of the Tualatin basin, the depth of which is $-390 \mathrm{~m}$.

The top CRBG horizon is exposed at the surface along the perimeter of the study area (Fig. 1; Wells et al., 2020a). The horizon reaches a maximum elevation of roughly $640 \mathrm{~m}$ at Dutch Canyon, northwest of the Portland Hills (Fig. 5). Structure map rugosity reflects the resolution of the $10 \mathrm{~m}$ regional DEM in areas where CRBG is exposed at the surface, particularly along the Portland Hills, Dutch Canyon, and the margins of the Tualatin basin. Mapped faults, which generally strike NW-SE, coincide with steep gradients on the structure map (Wells et al., 2020a) Elevation decreases markedly northeast of the East Bank fault, with a gently sloping surface between it and the Portland Hills fault. The edge of the top CRBG surface terminates near the dextral Lacamas Lake and reverse Prune Hill and Blue Lake faults on the eastern side of the Portland basin. In the Tualatin basin, the top CRBG surface is elevated at 
Cooper Mountain, in the hanging wall of the Beaverton thrust (reverse) fault reaching a maximum elevation of $\sim 213 \mathrm{~m}$ (Fig. 5). This is nearly $\sim 600 \mathrm{~m}$ higher than the same surface in its footwall to the north. South of the Beaverton fault, the CRBG forms a complex fold belt in the hanging wall (Wells et al., 2020a, 2020b; diagonal-hatch pattern in Fig. 5) The dextral Canby-Molalla fault (Blakely et al., 2000) links up with the Beaverton fault to the southeast, near the eastern edge of this complex domain, following the interpretation of Wells et al. (2020a).

There are a few locations in the study area where CRBG is missing, and pre-CRBG sedimentary rock is exposed at the surface (cross-hatch pattern in Fig. 5). Dutch Canyon, the core of an eroded anticline, exposes older Paleogene and early Miocene sediments at the surface. These same sedimentary rocks are exposed in a small area on the southwest flank of the Portland Hills along the Sylvan-Oatfield fault. CRBG is also missing where it laps onto Eocene basalt exposed south of the Portland Hills near Waverly Heights (Fig. 5).

\section{Base CRBG}

The base CRBG horizon is exposed at the surface around the western margin of the Tualatin basin, in Dutch Canyon, and the southwest flank of the Portland Hills (Wells et al., 2020a). Exposed pre-CRBG sedimentary rock is denoted with a cross-hatch pattern on Figure 6 . In the centers of the basins, the base CRBG horizon (Fig. 6) is poorly constrained because fewer wells penetrate the horizon in the subsurface, and base CRBG is not as easily resolved in seismic images (Wilson, 1997; Liberty, 2002). Despite these uncertainties, our results show that the base CRBG horizon reaches lower elevations in the Portland basin at $-820 \mathrm{~m}$ relative to the Tualatin basin, which is $-730 \mathrm{~m}$, similar to the pattern observed from our results of the top CRBG. The surface reaches a maximum elevation of roughly $570 \mathrm{~m}$ at Dutch Canyon (Fig. 6).

Similar to the top CRBG horizon, faults are generally coincident with steep elevation gradients on the base CRBG structure map (Fig. 6). The Sylvan-Oatfield and Portland Hills faults bound a

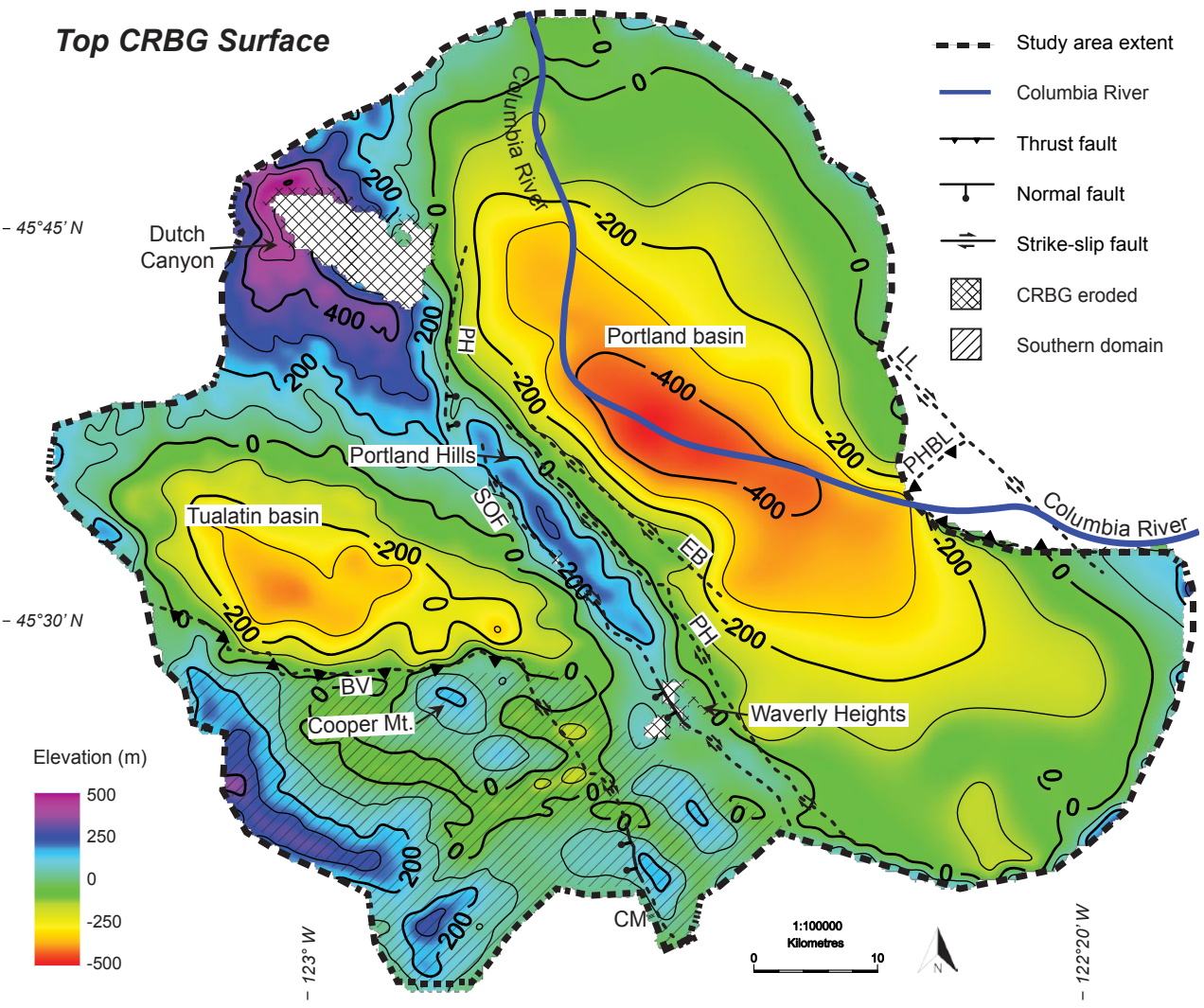

Figure 5. Structural contour map of top Columbia River Basalt Group (CRBG). The top CRBG surface is exposed along the Portland Hills anticline, which separates the Portland and Tualatin basins, and along the southwestern margin of the Tualatin basin. Cool colors reflect higher elevations, and warm colors reflect lower elevations. Contour interval $=100 \mathrm{~m}$. Dashed faults are inferred as in Wells et al. (2020a). Location of the Columbia River shown for reference. BV-Beaverton fault: CM-Canby-Molalla fault: SOF-Sylvan-Oatfield fault: PH - Portland Hills fault: EB-East Bank fault: PHBL-Prune Hill/2 - Canby

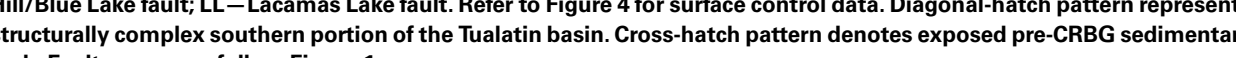
rock. Fault acronyms follow Figure 1.

northwest-trending structure of higher elevation coincident with the Portland Hills. The inferred north west extension of the Portland Hills fault matches a steep gradient that offsets the Portland basin down to the southeast. Similar to the top CRBG surface, elevation decreases markedly northeast of the East Bank fault. A gently sloping surface lies between the East Bank and the Portland Hills fault. At the location of Cooper Mountain in the Tualatin basin, this surface reaches an elevation of about $-100 \mathrm{~m}$ in the hanging wall of the Beaverton thrust fault and decreases to $-488 \mathrm{~m}$ in its footwall to the north.

\section{Eocene Basement}

The gravity-derived depth to basement grid of McPhee et al. (2014) reveals a deep depression 
underneath the Tualatin basin, which gradually increases in elevation toward the western Cascades to the east (Fig. 7). The surface is over twice as deep in the Tualatin basin at $-5.7 \mathrm{~km}$ compared to the Portland basin, the depth of which is $-2.1 \mathrm{~km}$. In the southeastern portion of the Portland basin, western Cascade arc rock is more dense than that assumed for basin fill in the gravity inversion (McPhee et al., 2014). This causes an erroneous shallowing of basement in that area and is denoted by a diagonal-hatch pattern on Figure 7. The surface increases to a local high of roughly $-0.9 \mathrm{~km}$ at the Dutch Canyon anticline.

In many cases, modeled faults are also coin cident with gradients on the Eocene basement structure map, suggesting they deform basement The Sylvan-Oatfield and Portland Hills faults follow two northwest-trending basement highs at the boundary between the Portland and Tualatin basins. Basement elevation ranges from roughly $-1.7 \mathrm{~km}$ to $-2.1 \mathrm{~km}$ in a low that coincides with the Portland Hills anticline. In the Tualatin basin, the basement surface lies at $-2.3 \mathrm{~km}$ elevation in the hanging wall of the Beaverton fault, decreasing from roughly $-3.4 \mathrm{~km}$ to $-4.5 \mathrm{~km}$ in its footwall to the north (Fig. 7).

\section{Post-CRBG Sedimentary and Volcaniclastic Rocks (0-15 Ma)}

The post-CRBG (0-15 Ma) isochore map reveals two distinct northwest-trending depocenters coincident with the Portland and Tualatin basins (Fig. 8). Slightly more sediments were deposited in the Portland basin at roughly $500 \mathrm{~m}$ thick compared to the Tualatin basin, which reaches $445 \mathrm{~m}$ thick over this time period. Sedimentary rocks thin onto the Portland Hills where CRBG is exposed (Fig. 1). Isolated "bull's-eyes" of 430-460-m-thick basin fill in the southern portion of the Portland basin incorporate volcanic cones of the post-CRBG Boring Volcanic Field. Relatively thick sedimentary deposits in the southernmost portion of the Portland basin continue out of the study area, into the Northern Willamette Valley.

Modeled faults in the study area mark abrupt changes in 0-15 Ma sediment thickness (Fig. 8).

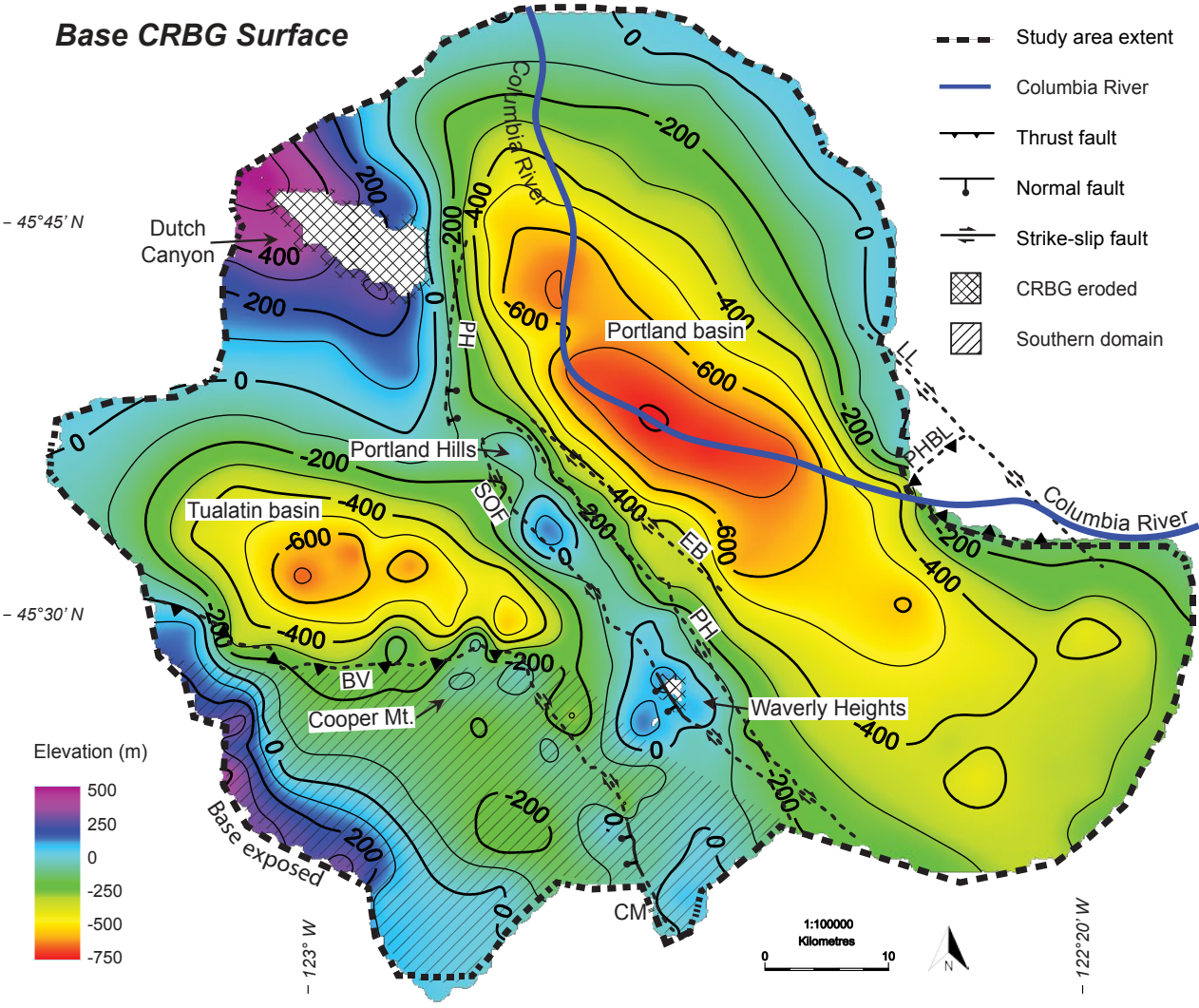

Figure 6. Structural contour map of base Columbia River Basalt Group (CRBG). Regions of higher elevation (cool colors) along the Portland Hills separate the Portland and Tualatin basins. The base CRBG surface is exposed in outcrop around Dutch Canyon and the southwest margin of the Tualatin basin. Contour interval $=100 \mathrm{~m}$. Dashed faults are inferred as in Wells et al. (2020a). Location of the Columbia River shown for reference. BV-Beaverton fault; CM-Canby-Molalla fault; SOF-Sylvan-Oatfield fault: PH - Portland Hills fault: EB - East Bank fault: PHBL-Prune Hill/Blue Lake fault: L - Lacamas Lake fault Refer to Figure 4 for surfece control data. Diagona-hatch pattern represents structurally complex southern portion The

The inferred northern continuation of the Portland Hills fault reveals a steep thickness gradient along its footwall with thicknesses up to $\sim 30 \mathrm{~m}$ in its hanging wall (to the southwest). Similarly, the East Bank fault bounds a steep thickness gradient to its northeast, shown by a transition from warm colors (thick) to cool colors (thin) to the southwest (Fig. 8). A significant change in thickness is also observed across the Beaverton fault in the Tualatin basin.

\section{Mid-Miocene Columbia River Basalt Group (15.5-16.5 Ma)}

The CRBG (15.5-16.5 Ma) isochore map reveals multiple depocenters across the mid-Miocene Portland and Tualatin basins, with basalt flows generally thinning west of the NW-striking Portland Hills fault zone (Beeson et al., 1989a; Fig. 9). On average, thick ness of CRBG is comparable between the centers of the basins, with $275-330 \mathrm{~m}$ in the Portland 
basin and $275-365 \mathrm{~m}$ in the Tualatin basin. CRBG remains relatively thick south toward the Northern Willamette Valley where the Trans-arc Lowland and Sherwood trough of Beeson et al. (1989a) extend southwest toward a gap in the Coast Range. The CRBG thins prominently over the structural highs of Waverly Heights and Dutch Canyon (Fig. 9).

An elongate region of local thickening coincident with the Portland Hills is bound by the Sylvan-Oatfield and Portland Hills faults. Between the faults, the basalt ranges from $\sim 215-300 \mathrm{~m}$ thick. Along the trace of the faults, the basalt thins to $\sim 90-180 \mathrm{~m}$ before thickening again toward the central Portland and Tualatin basins (to the east and west, respectively) (Fig. 9). The East Bank fault juxtaposes an area of thick basalt to the northeast, against basalt that is $\sim 60-120 \mathrm{~m}$ thinner to the southwest. Relatively thick CRBG exists south of the Beaverton fault near Cooper Mountain and in the Sherwood trough. However, uncertainty in this area is high because of the poor constraints on the base of the CRBG.

\section{Early Miocene to Late Eocene (ca. 17-35 Ma)}

The pre-CRBG early Miocene to late Eocene (ca. 17-35 Ma) isochore map reveals one distinct depocenter coincident with the western edge of the Tualatin basin (Fig. 10). Early Miocene to Eocene sedimentary rocks thin gradually from the Tualatin basin east toward the Portland basin and western Cascades. Maximum sediment thickness reaches $\sim 5.2 \mathrm{~km}$ in the Tualatin basin and $\sim 1.5 \mathrm{~km}$ in the Portland basin. We observe a minimum thickness of $\sim 1 \mathrm{~km}$ in the core of the Dutch Canyon anticline. Relative uncertainty of sedimentary rock thickness in the southern portion of the Portland basin is denoted by a diagonal hatch pattern.

Similar to the CRBG isochore, it appears there is an area of local thickening that coincides with the Portland Hills bound by the Sylvan-Oatfield and Portland Hills faults. Here, sediment thickness ranges from $\sim 1.5-1.8 \mathrm{~km}$ and decreases to a thickness of $\sim 0.9-1.2 \mathrm{~km}$ on its flanks. In the southwest portion of the map, the isopach thickness decrease significantly across the Beaverton fault, suggesting it was active during this time. Significant changes

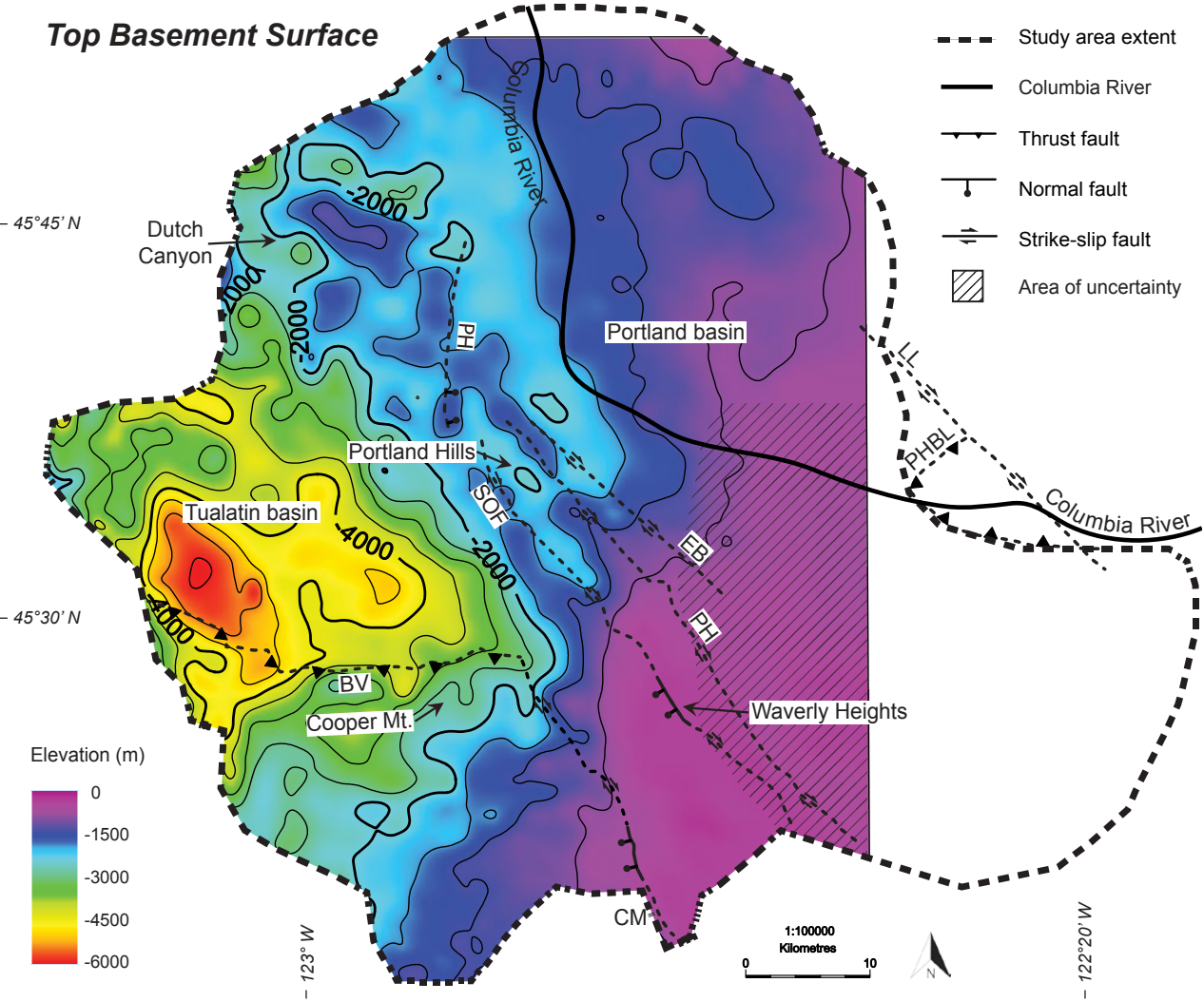

Figure 7. Structural contour map of Eocene basement based primarily on gravity data from McPhee et al. (2014). The elevation is lowest in the Tualatin basin (warm colors) and shallows to the east across the Portland basin (cool colors). There is a localized basement low under the Portland Hills. Eocene basement is exposed in the vicinity of Waverly Heights (Fig. 1; Wells et al., 2020a). Contour interval $=500 \mathrm{~m}$. Dashed faults are inferred as in Wells et al. (2020a). Location of the Columbia River shown for reference. B-Beaverton fault: CM - Canby-Molalla fault: SOF-Sylvan-Oatfield fault: PH Portland Hills fault; EB-East Bank fault: PHBL-Prune HillBlue Lake faut: $L$-Lamas Lake fault. Refer to Figure 4 for (a) 4 for density assumptions used in the gravity inversion of McPhee et al. (2014). Fault acronyms follow Figure 1.

in thickness are not observed across the Canby-Molalla fault.

\section{DISCUSSION}

Our results show that Portland and Tualatin basin depocenters have shifted in both location and shape over time We interpret spatio-temporal changes in basin thickness as related to changes in stress within the Cascadia forearc and emergence of the Oregon Coast Range.

\section{Paleogene Spatio-Temporal Changes}

A cross section through the Portland and Tualatin basins (Fig. 11) based on well-log, seismic, and 
gravity data suggests substantial vertical displacement of basement in pre-CRBG time along northwest-striking faults now interpreted as Quaternary active strike-slip faults (Beeson et al., 1985, 1989a; Beeson and Tolan, 1990; Yelin and Patton 1991; Blakely et al., 2000, 2004; Wells et al., 2020a). McPhee et al. (2014) interpreted the 5-km-deep Paleogene Tualatin basin as a releasing-bend stepover between the Gales Creek and Portland Hills faults, creating accommodation space prior to CRBG emplacement. However, there is sedimentary evidence that the Tualatin basin was on the continental shelf during this time and likely, an inboard extension of the Astoria-Nehalem basins (Niem and Niem 1985; Niem et al., 1992b). During Paleogene time both the Tualatin and Astoria-Nehalem basins are dominated by marine shelf and slope sedimentary strata (Niem et al., 1992b; Wilson, 1997). The thickness of the late Eocene to Oligocene Pittsburg Bluff formation does not change significantly across the Coast Range, where these rocks are documented in hydrocarbon exploration wells and exposed in outcrop (Niem et al., 1992b, 1992a), demonstrating that this unit was likely deposited at a relatively uniform thickness rather than thinning onto a preexisting high. Thinning of the ca. 17-35 Ma isochore map to the west onto the present-day Coast Range (Fig. 11) is primarily due to erosion, as $\sim 4 \mathrm{~km}$ of Paleogene and early Neogene marine strata are mapped in the foothills of the Coast Range, dipping gently east into the Tualatin basin (Seismic line WV-1, Oregon Department of Geology and Mineral Industries, 2012; Wells et al., 2020a, 2020b).

We estimate an average sediment accumulation rate in the Tualatin basin of $\sim 286 \mathrm{~m} / \mathrm{Ma}$ from Paleogene to early Miocene time based on a thickness of $\sim 5300 \mathrm{~m}$ and age range of ca. 17-35 Ma. This is similar to sediment accumulation rates in the Astoria basin during Oligocene time ( $275 \mathrm{~m} / \mathrm{Ma})$, esti mated from well-log data (Niem and Niem, 1985) These sediment accumulation rates are within the range of typical marine basins at convergent boundaries and represent sedimentation on the continental shelf and slope prior to the creation of the Coast Range and Portland Hills (Schwab, 1976).

Paleogene sedimentary rocks in the Tualatin basin are modeled to be $\sim 5 \mathrm{~km}$ thick, producing

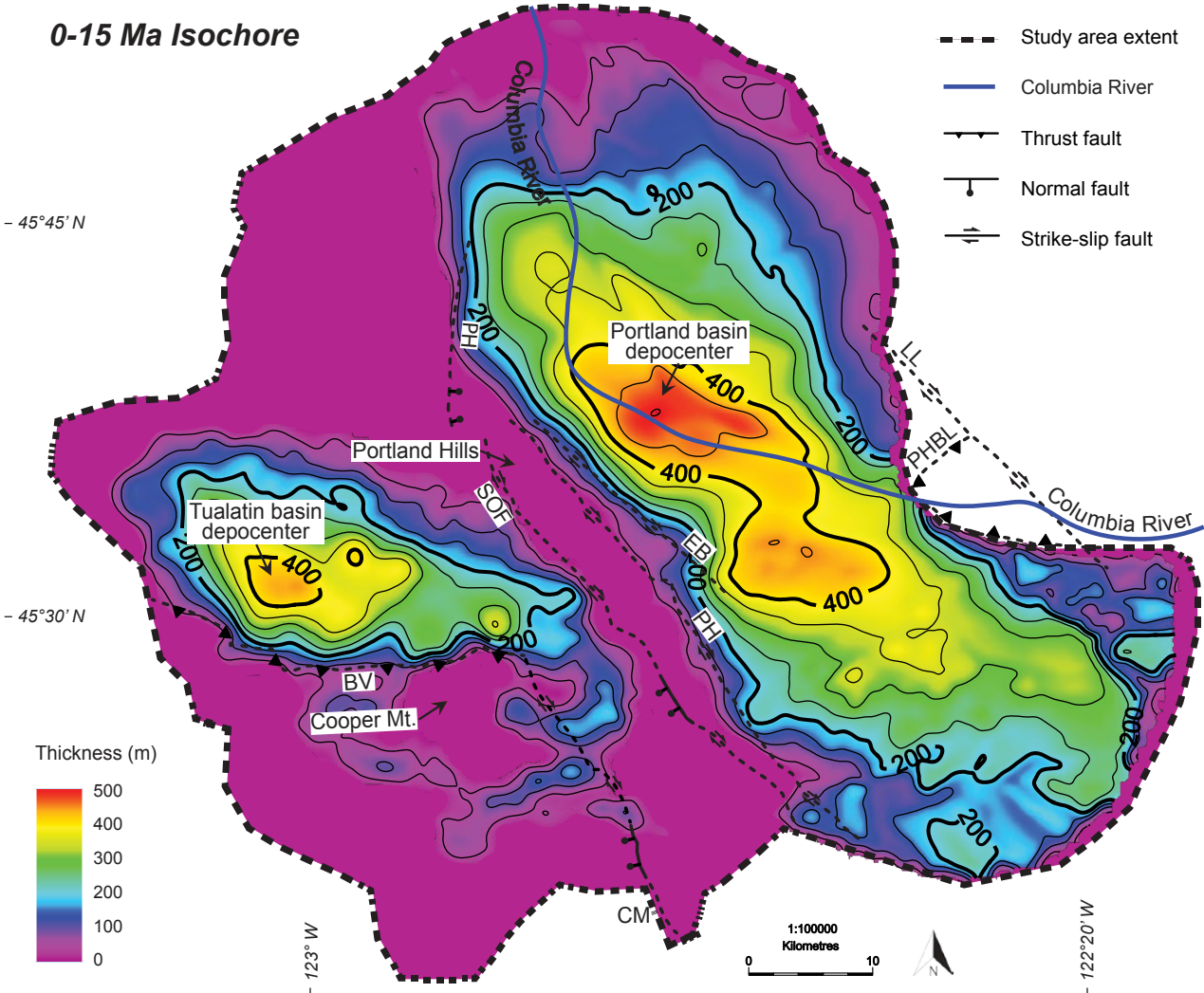

Figure 8. Post-Columbia River Basalt Group (CRBG) sedimentary overburden (0-15 Ma) isochore map generated as the difference between digital elevation model (DEM)-derived topography and top CRBG structure map. The northeast extension of the Portland Hills fault is shown southeast of Dutch Canyon. Thickness packages $<\sim 1 \mathrm{~km}$ diameter are likely an interpolation artifact. Contour interval $=50 \mathrm{~m}$. Location of the Columbia River shown for reference. BV-Beaverton fault: CM-Canby-Molalla fault; SOF-Sylvan-Oatfield fault: PH - Portland Hills fault; EB-East Bank fault: PHBL-Prune Hill/Blue Lake fault; LL-Lacamas Lake fault. Fault acronyms follow Figure 1.

a $-44 \mathrm{mGal}$ gravity low (McPhee et al., 2014). They thin eastward toward the Paleogene coastline, which was near the western Cascades (Fig. 10; Niem et al., 1992b; Retallack et al., 2004; Evarts et al., 2009). The interfingering of marine sedimentary rocks with Cascade arc-derived volcanics suggests deposition prior to the emergence of a subaerial Coast Range ca. $20 \mathrm{Ma}$ (Armentrout, 1983; McKeel, 1984; Stanley, 1991; Niem et al., 1992a; Snavely and Wells, 1996). Our early Miocene to Eocene isochore map shows the Paleogene basin depocenter was $>100 \mathrm{~km}$ to the west of the modern Cascade arc with basement elevations increasing to the east (Figs. 10 and 11). This is consistent with Evarts et al. (2009), who suggest that Paleogene and early Miocene sedimentary rocks interfingered with western Cascade volcanics at the Paleogene coastline.

A $-28 \mathrm{mGal}$, northwest-striking gravity low centered over the Portland Hills coincides with 1.5$1.8 \mathrm{~km}$ of Paleogene and early Miocene sedimentary 
rocks bound by the dextral Sylvan-Oatfield and Portland Hills faults (Fig. 10). We interpret this geometry as requiring early normal displacement on these steeply dipping $\left(\sim 70^{\circ}\right)$ faults that offset the basement surface, creating a graben at the present-day location of Portland Hills, into which a thicker package of Paleogene and early Miocene sediments were deposited (Fig. 13). This interpretation is supported by the Barber \#1 exploration well, located in the Portland Hills, which penetrates $\sim 2.1 \mathrm{~km}$ of volcanic rock, agglomerate, and sands (Newton, 1969). Faulting likely continued during episodic Paleogene north-northwest-directed extension, consistent with Eocene normal faulting in the Mist gas field (Niem and Niem, 1985), and the eruption of Eocene tholeiitic and alkalic basalts where the Coast Range is today (e.g., Tillamook Highlands) and offshore (Wells et al., 1984, 2014; Snavely and Wells, 1991, 1996; Snavely et al., 1993) Rift flank uplift along the edges of the Portland Hills graben (a graben coinciding with the present-day location of the Portland Hills), resulted in up to couple hundred meters of relief along the northeas margin of the Tualatin basin and southwest margin of the nascent Portland basin (Fig. 13)

\section{Neogene Spatio-Temporal Changes}

\section{Columbia River Flood Basalts}

Middle Miocene flood basalts of the CRBG inundated the Portland and Tualatin basins following the ancestral Columbia River to the sea (Beeson et al 1989a; Beeson and Tolan, 1990; Reidel et al., 2013; Wells et al., 2020a). Significant variation in flow thickness is evident in our CRBG (15.5-16.5 Ma) isochore map (Fig. 9), suggesting that there was preexisting topography. Basalt lava flows were deposited onto the Eocene basalt of Waverly Heights, incipient western Cascade arc, Goble Vo canics, Dutch Canyon anticline, and Paleogene to early Miocene sediments (Figs. 9 and 11; Beeson et al., 1989a, 1989b). Our basin model shows that flow paths were influenced by the major northwest-striking fault zones that still dominate the study area (Beeson et al., 1989a; Anderson et al., 2013; Reide

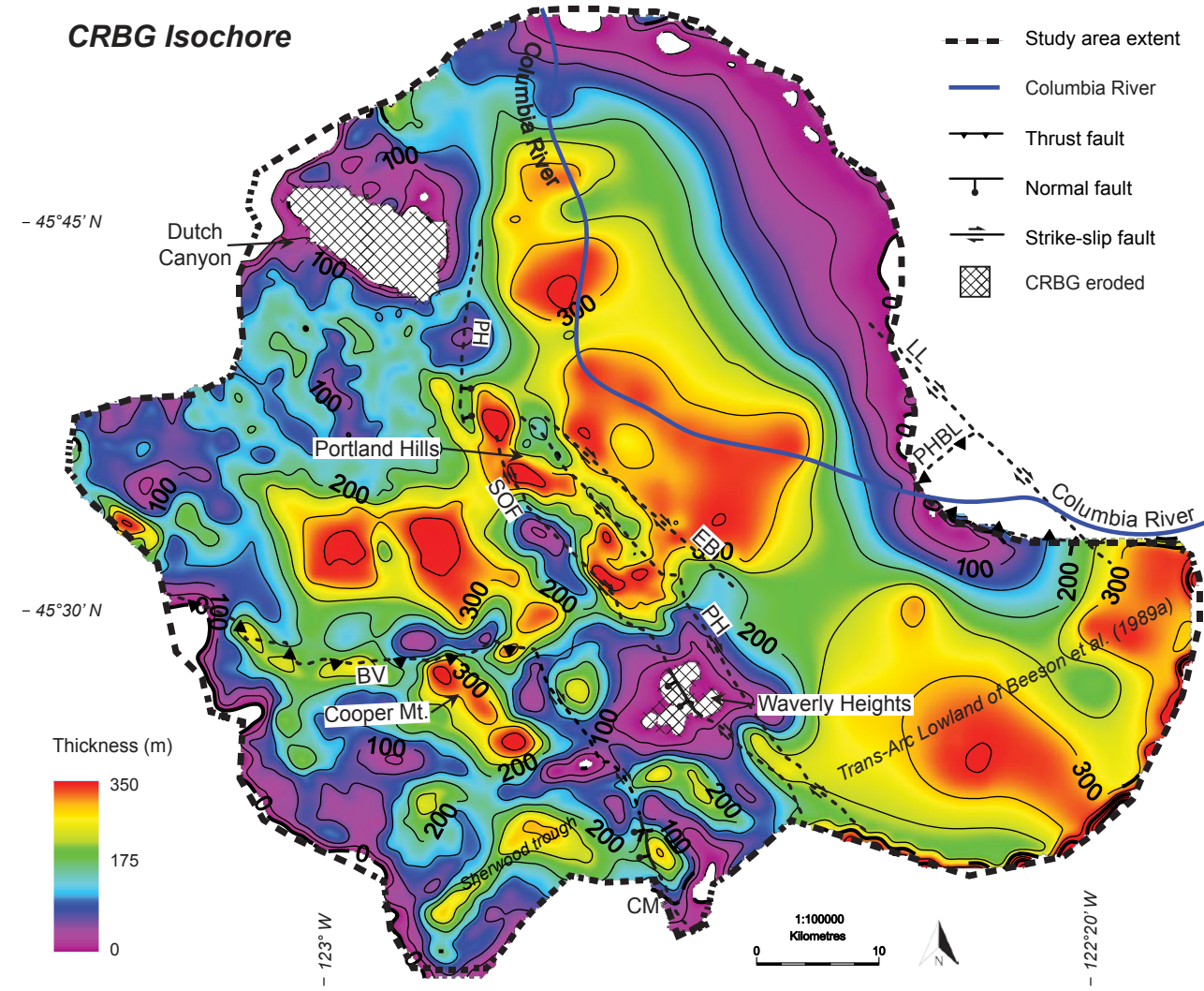

Figure 9. Mid-Miocene Columbia River Basalt Group (CRBG) (15.5-16.5 Ma) isochore map generated as the difference between the top and base CRBG structure maps. CRBG thickness is similar in both the Portland and Tualatin basins. Thickness packages $<\sim 1 \mathrm{~km}$ diameter are likely an interpolation artifact. Contour interval $=50 \mathrm{~m}$. Location of the Columbia River shown for reference. BV-Beaverton fault; $\mathrm{CM}$-Canby-Molalla fault; SOF-Sylvan-Oatfield fault; PH - Portland Hills fault; EB - East Bank fault; PHBL - Prune Hill/Blue Lake fault; LL-Lacamas Lake fault. Cross-hatch pattern denotes exposed pre-CRBG sedimentary rock. Fault acronyms follow Figure 1.

et al., 2013), forming a graben that was filled by CRBG. Previous workers have suggested that an incipient Portland Hills anticline diverted the earliest Grande Ronde Basalt flows of the CRBG $\left(\mathrm{R}_{1} / \mathrm{N}_{1}\right.$ magnetic polarity), limiting their extent to the Portland basin (Beeson et al., 1989a; Evarts et al., 2009). However, the discovery of Downey Gulch and China Creek flows of the Grande Ronde Basalt $\left(\mathrm{N}_{1}\right.$ magnetic polarity) in the Tualatin basin suggests these early flows inundated the Tualatin basin as well
(T.L. Tolan, 2004, written commun.; Dinterman and Duval, 2009; USGS, 2013; Wells et al., 2020a). Our CRBG isochore map, based in part on well data that bottom in the $\mathrm{R}_{2}$ Wapshilla Ridge unit in the Portland basin (Well MULT 106000) and older $\mathrm{N}_{1}$ China Creek Member (Well WASH 55816) in the Tualatin basin, suggests the two basins were still connected at ca. 16.5 Ma (USGS, 2013).

CRBG flows thin $\sim 60-90 \mathrm{~m}$ across the rift flanks of the Portland Hills graben. Within the graben, 
flows reach thicknesses of up to $\sim 240-300 \mathrm{~m}$ (Figs. 9 and 12). These thickness estimates are reasonably constrained by both well and outcrop data (Table S2 [footnote 1]). Previous geologic mapping suggests that flows thinned depositionally onto gravity highs associated with the Eocene basalt of Waverly Heights and the Dutch Canyon anticline prior to inundating the Tualatin basin (Beeson et al., 1989b, 1991), though erosion associated with rift flank uplift was also likely. Later flows encountered less topography as earlier flows filled in preexisting lows, which is reflected in the widespread distribution of ca. 15.5 Ma Sentinel Bluffs flows of the Grande Ronde Basalt during $\mathrm{N}_{2}$ time (Beeson et al., 1989a).

\section{Post-CRBG Structural Inversion}

Our basin model suggests that faults in the Portland and Tualatin basins were structurally inverted following the emplacement of the CRBG in mid-Miocene time, recording a change in stress from transtension to transpression in the forearc The dextral Sylvan-Oatfield and Portland Hills faults, which bounded the Portland Hills graben during Paleogene to early Miocene time, provided planes of weakness exploited by transpressive stress in midto late Miocene time, resulting in structural inversion (Fig. 13; Sibson, 1985; Sibson et al., 1988; Letouzey et al., 1990). Fault geometries characteristic of inversion are supported by regional aeromagnetic data that suggest the Sylvan-Oatfield and East Bank faults are steeply dipping structures with reverse slip (Blakely et al., 1995) and described by Beeson et al. (1989a) as flower structures. Our CRBG isochore map indicates that structural inversion did not occur until sometime after CRBG was deposited in mid-Miocene time as CRBG thickens at the present-day location of the Portland Hills (Fig. 9). A change from transtension to transpression in mid- to late Miocene time is consistent with the onset of shortening in Washington State documented in accelerated uplift of the Washington Cascades (Reiners et al., 2002), north-south shortening along the Seattle fault (ten Brink et al., 2002), and across the Yakima fold and thrust belt (Reidel et al. 1989; McCaffrey et al. 2016).

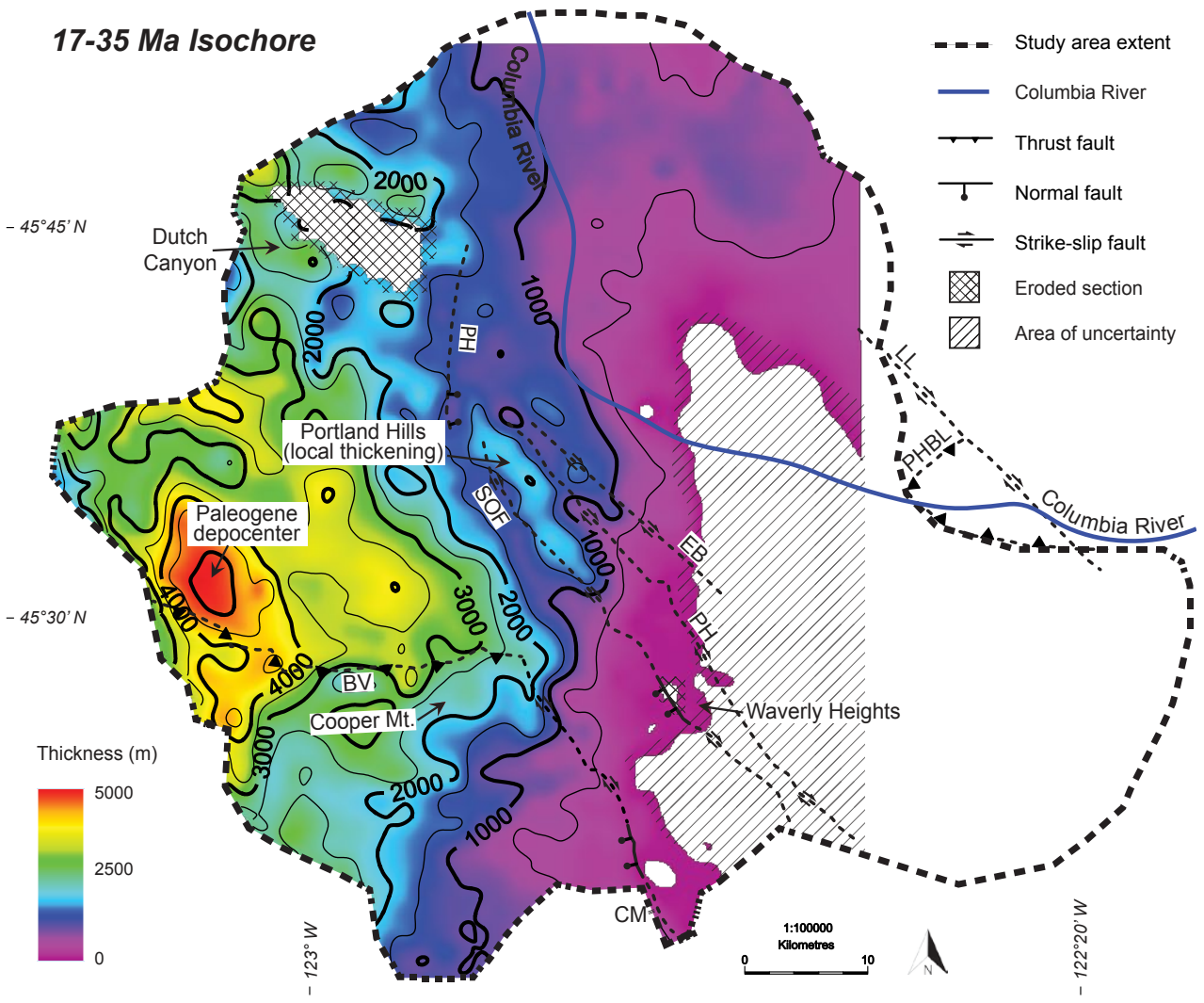

Figure 10. Early Miocene to late Eocene (ca. 17-35 Ma) isochore map generated as the difference between the base Columbia River Basalt Group (CRBG) and Eocene basement structure maps. Thickness packages $<\sim 1 \mathrm{~km}$ diameter are likely an interpolation artifact. Contour interval $=500 \mathrm{~m}$. Location of the Columbia River shown for reference. BV-Beaverton fault; CM - Canby-Molalla fault; SOF-Sylvan-Oatfield fault; PH - Portland Hills fault; EB-East Bank fault; PHBL-Prune Hill/Blue Lake fault: LL-Lacamas Lake fault. Cross-hatch pattern denotes exposed pre-CRBG sedimentary rock. Diagona hatched pattern represents are of uncertainty in gravity-derived basement surface due to density assumptions used in the gravity inversion of McPhee et al. (2014). Fault acronyms follow Figure 1.

The east-west-trending Beaverton fault in the southern Tualatin basin also shows evidence of structural inversion in mid- to late Miocene time. Cooper Mountain, a post-CRBG fold with an eastwest-trending axis in the hanging wall of the Beaverton fault shows stratigraphic offset on the top CRBG surface consistent with reverse deformation on a fault dipping to the south (Fig. 5). Other, approximately east-west-striking folds in the area (i.e., Parrett Mountain and the Chehalem Mountain uplift) also formed in response to north-south shortening (Beeson and Tolan, 1990). However, our CRBG isochore map shows that CRBG is relatively thick in the hanging wall, suggesting the Beaverton fault was a normal fault in the mid-Miocene (Fig. 9). McPhee et al. (2014) has also suggested that the Beaverton fault is an inversion structure that formed as a normal fault in response to north-northwest 


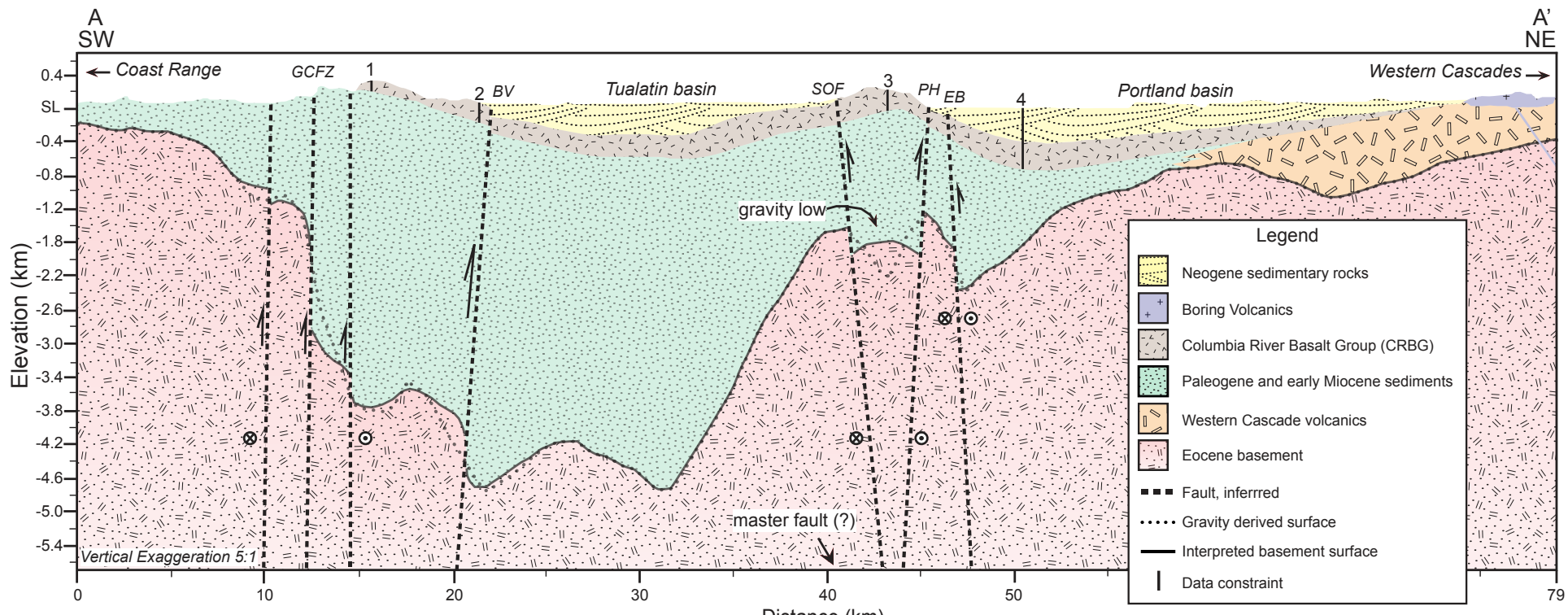

Figure 11. Geologic cross section A-A' including all modeled units down to Eocene basement. Location of cross section shown in Figure 1. Basement (solid line) offsets are interpreted from the surface derived from residual gravity data (dotted line) of McPhee et al. (2014). Data constraints: 1-WASH 206 (ID\# 2206); 2-WASH 633 (ID\#2207); 3-Interpolation guide (ID\# 2201); 4-Pick from Portland basin seismic profiles of Liberty (2002) (ID\# 1667) (see text footnote 1). Vertical exaggeration 5:1. GCFZ-Gales Creek Fault Zone. All other fault acronyms follow Figure 1 .

Paleogene Forearc: ca. $34 \mathrm{Ma}$

A West $\begin{gathered}\text { Broad forearc basin, } \\ \text { post-42 Ma rifting and forearc volcanism }\end{gathered}$

Neogene Forearc: ca. $0 \mathrm{Ma}$

B West Coast Range

Figure 12. Schematic cross sections of the Cascadia Forearc during Paleogene and Neogene time. (A) During late Paleogene time, the Portland and Tualatin basins were continuous and part of a more extensive marine basin that extended west across the continental shelf. $\mathrm{Pa}$ leogene strata are stippled. The Coast Range was not a significant topographic feature at that time. Localized subsidence in the Portland and Tualatin basins may have been related to rifting. (B) During Neogene time, flood basalts of the Columbia River Basalt Group (CRBG) flowed across the forearc to the sea. Following the eruption of the CRBG, the Coast Range emerged, possibly due to the subduction of younger, more possibly due to the subduction of younger, more bion oceastic tion space in the Portland and Tualatin basins and lowering sediment accumulation rates ten-fold. Regional stress became transpressive, inverting faults and giving rise to the Portlan Hills (PH). 


\section{Research Paper}
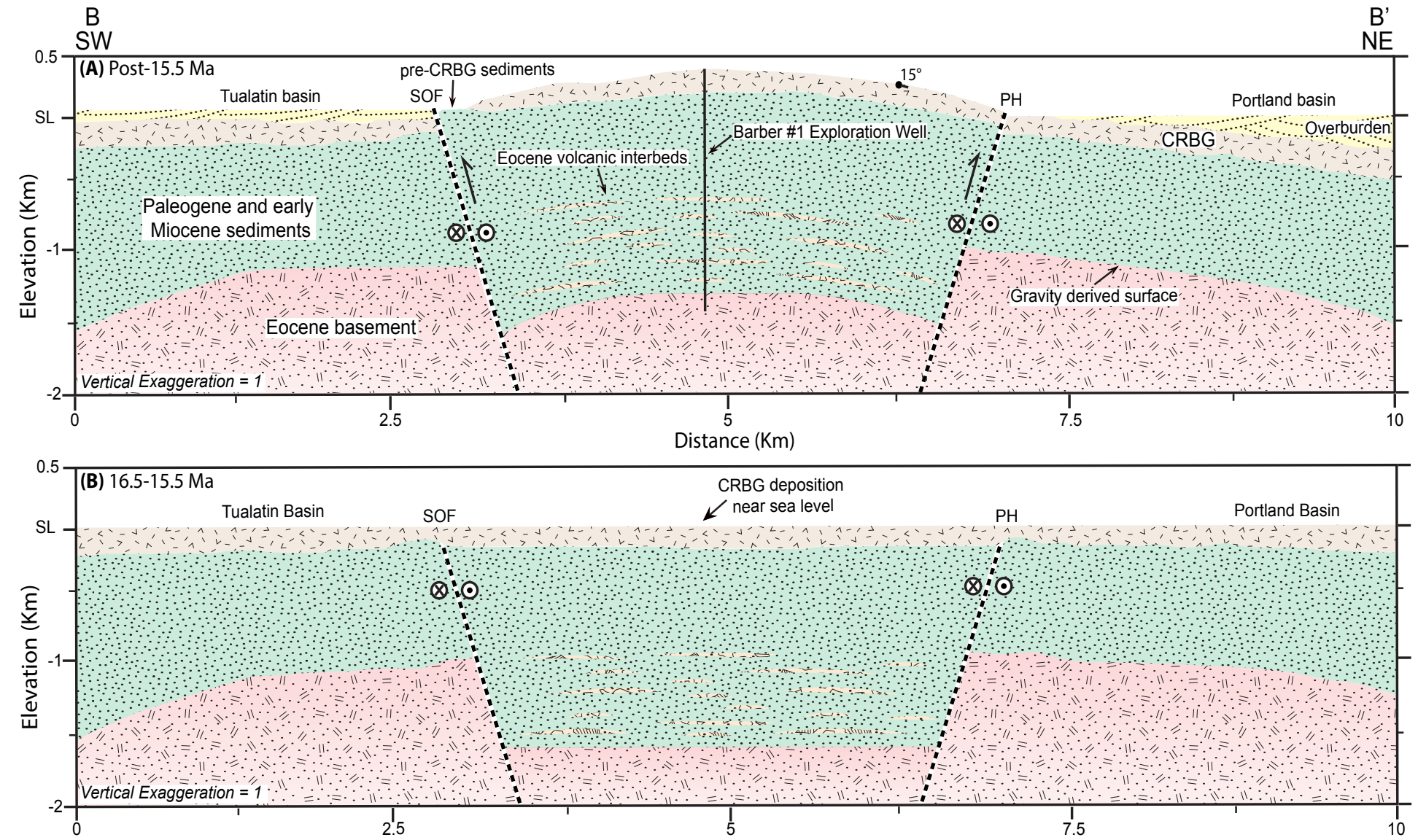

(1)

Figure 13. Cross section $B-B^{\prime}$ depicting mid- to late Miocene structural inversion of the Portland Hills uplift. Location of cross section shown in Figure 1. Prior to Columbia River Basalt Group (CRBG) deposition, normal faulting on the Sylvan-Oatfield and Portland Hills faults resulted in a graben with uplifted flanks on either side relative to the nascent Portland and Tualatin basins (Panel C). Localized normal faulting continued up until the time of CRBG deposition, resulting in preexisting topography (Panel B). This topography played an important role in controlling CRBG flow emplacement, where basalt flows are thicker in topographic lows and thinner on relative highs (Beeson et al., 1989a). Post-CRBG emplacement, normal faults were reactivated as high-angle reverse faults, resulting in the Portland Hills uplift (Panel A). Structural inversion was likely in response to the steady inversion wase rotation and northward migrateady the Cos The location of the Batser 11 exploration will. The location of the Barber thexploration well constrains the thickness of Paleogene to early Miocene sedimentary rocks under the Portland Hills and is shown as a black solid line. Bedding orientations based on field mapping are depicted as tadpole with dip value (Wells et al., 2020a). Depth to basement is from McPhee et al. (2014), derived from inversion of gravity data. No vertical exaggeration. $S L=$ sea level. Unit colors and patterns are consistent with the legend in

Figure 11. Fault acronyms follow Figure 1.

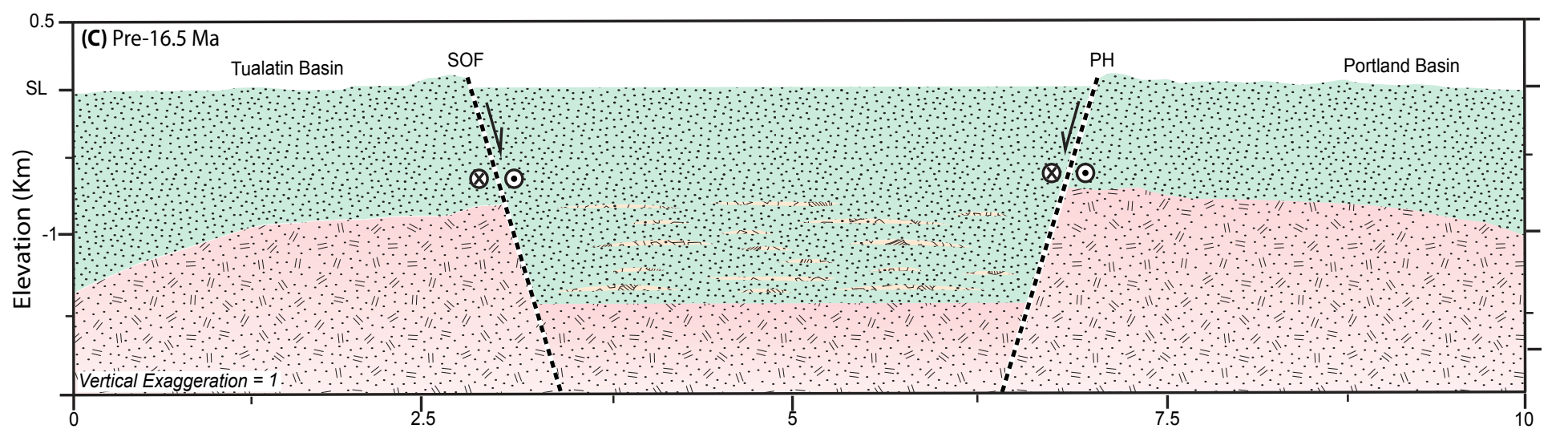


extension in Paleogene time. Structural inversion in the Tualatin and Portland basins is also consisten with the history of deformation on the continenta shelf in Oregon where normal faults were reactivated as thrust faults during late mid-Miocene transpression (Snavely and Wells, 1996). Our work provides evidence of a major change in the stress regime from transtension in Paleogene time to transpression in Neogene time.

The existence of distinct mid-Miocene to Pleistocene depocenters in the Portland and Tualatin basins suggests they were effectively separated by the Portland Hills during this time, consistent with petrographic analysis of the Tualatin basin fill (Fig. 8; Wilson, 2000). It is likely that basin separation was synchronous with structural inversion in mid- to late Miocene time since the Portland Hills consists entirely of CRBG blanketed by loess of the Missoula floods (Evarts et al., 2009). The location of the Portland basin depocenter during late Neogene time suggests that the East Bank fault is exerting local control on accommodation space. Our 0-15 Ma isochore map shows that post-CRBG basin fill in the Portland basin is $\sim 55 \mathrm{~m}$ thicke than in the Tualatin basin, providing further ev dence that uplift of the Oregon Coast Range has progressively pushed the forearc basin depocente eastward through Neogene time (Fig. 12). In the Puget Sound to the north, where lateral separation between the accretionary wedge (Olympics) and magmatic arc (Cascades) is greater, the Seattle basin reaches a maximum depth of $\sim 9 \mathrm{~km}$, nearly $\sim 3 \mathrm{~km}$ deeper than the Tualatin basin (Johnson et al., 1994; Symons and Crosson, 1997; Rau and Johnson, 1999; Blakely et al., 2002; ten Brink et al 2002; McPhee et al., 2014). Most of this difference is attributed to Neogene ( $<20 \mathrm{Ma}$ ) sedimentary rocks in the Seattle basin, which are significantly thicke than contemporaneous rocks in the Portland basin $(\sim 3.6 \mathrm{~km}$ thick versus $\sim 500 \mathrm{~m}$ thick, respectively) (Fig. 13; Johnson et al., 1994). Relatively thin Neogene deposits in the Portland basin are not due to low sediment supply as the Columbia River traverses the area. In the Portland basin, a relatively short distance between the Coast Range and Cascades has reduced accommodation space since the

Miocene. In the Seattle basin, there is still sufficient separation between the two; thus, accommodation space remains. Accordingly, we suggest that the location of the Oregon Coast Range and Olympic Mountains uplift relative to the magmatic arc has exerted a first-order control on forearc basin accommodation space since Miocene time, not only in the Portland and Tualatin basins, but likely along the entire Cascadia forearc from the southern Willamette Valley to the Puget Sound.

Average sediment accumulation rates across 0-15 Ma strata in the Portland and Tualatin basins are $\sim 30 \mathrm{~m} / \mathrm{Ma}$, consistent with late Miocene to late Pliocene rates for the Tualatin basin estimated by Wilson (1997). This is an order of magnitude less than sediment accumulation rates estimated for Paleogene to early Miocene strata and is consistent with the forearc transition from a marine basin in an environment of extension (more accommodation space) to a continental forearc basin currently undergoing shortening (less accommodation space). Because the top of the CRBG in the Portland and Tualatin basins is $\sim 370 \mathrm{~m}$ below sea level (Fig. 5), some tectonic subsidence in the forearc lowland has occurred since mid-Miocene time. It may be the result of ongoing flexure of the upper plate from the Cascadia magmatic arc load (e.g. Waltham et al., 2008), or possibly subduction erosion driven by negative volume changes in the subducting slab (Engebretson and Kirby, 1995; Rogers, 2002). The M 7.1 Anchorage earthquake of 2018 was an intermediate-depth (55-75 km) normal faulting event in the downgoing slab that caused subsidence of up to $3 \mathrm{~cm}$ in the overlying lowlands surrounding Cook Inlet (He et al., 2020).

We interpret the eastward shift of the Tualatin basin depocenter from the late Eocene to Miocene time as the result of Coast Range uplift. This is consistent with the introduction of marginal marine and continental sedimentary rock facies in the Astoria basin during early Miocene time (Niem et al., 1992a) Coast Range uplift also resulted in the deformation of Eocene to Oligocene marine strata forming a broad arch prior to CRBG emplacement (Wells et al., 1984; Parker, 1990; Werner, 1990). We suggest Neogene uplift of the Coast Range is the result of subducting progressively younger, more buoyant oceanic lithosphere, following the argument of
Rogers (2002). Plate motion models (e.g., Engebretson et al., 1985; Severinghaus and Atwater, 1990; Matthews et al., 2016) show 30-m.y.-old lithosphere entering the Cascadia subduction zone 30-35 m.y. ago, while today, the age of the incoming plate is $10 \mathrm{Ma}$ (Wilson, 2002). Age-depth relations for oceanic lithosphere (e.g., Niedzielski et al., 2016), show the average depth below sea level for 30-m.y.-old lithosphere is $\sim 4.1 \mathrm{~km}$, while the average depth for $10-\mathrm{m}$.y-old ocean lithosphere is $\sim 3 \mathrm{~km}$ depth. The decreasing age of the incoming plate could potentially lift the Oregon forearc as much as $1 \mathrm{~km}$. There are other processes that may have contributed to uplift of the Coast Range, including underplating of accreted sediments (Brandon et al., 1998; Calvert et al., 2011), extra buoyant asthenosphere (Bodmer et al., 2019), or permanent deformation driven by megathrust shear stresses (Dielforder et al., 2020), but the timing and amount of potential uplift from age-related slab buoyancy suggest it may play a long-term role in Coast Range uplift.

ncreased coupling with the obliquely subducting, more buoyant plate may also have contributed to the shift from transtensional to transpressive deformation in mid- to late Miocene time and set the stage for continued clockwise rotation and northward migration of the forearc, deformation observed today in the Portland and Tualatin basins (Wilson, 1997; Wells et al., 1998; McCaffrey et al., 2007, 2013; Evarts et al., 2009; McPhee et al., 2014) The present-day, transpressive deformation of the basins modifies their geometry and provides potential seismic sources around the basin margins. An improved understanding of the geometry and fill of the Portland and Tualatin basins presented here will be useful to continuing ground motion studies of the lowland (Frankel et al., 2018; Wirth et al., 2019)

\section{CONCLUSIONS}

Cascadia is one of a few subduction zones in which a coast range separates an inland sea from the forearc basins offshore. We show that although the Portland basin is separated from the Tualatin basin by the Portland Hills, analysis 
of an inversion of gravity data suggests that the two were connected as one continuous basin in the Paleogene, prior to CRBG deposition. During this time, it was an ocean basin with unlimited accommodation space. An eastward shift of the forearc basin depocenter over Neogene time is likely caused by uplift of the Coast Range to the west, restricting the basin and reducing accommodation space. Development of the subaerial Coast Range is the result of progressive subduction of increasingly younger and thus, more buoyant plate, consistent with the observation that similar margins seem to occur where young, warm slab is being subducted.

Local thickening of Paleogene sedimentary rocks and CRBG flows over a gravity low coincident with the NW-striking Portland Hills anticline suggest that it was a graben until mid- to late Miocene time. Neogene dextral transpression in the forearc structurally inverted the Sylvan-Oatfield and Portland Hills normal faults as high-angle, dextral-reverse faults, creating the Portland Hills anticline and effectively separating the Portland and Tualatin basins. This episode of structural inversion resulted from a regional change in stress from transtension to transpression. Decreased accommodation space due to Neogene uplift of the Oregon Coast Range and a change in regional stress caused a ten-fold decrease in sediment accumulation rates across the Portland and Tualatin basins, as they went from being part of a much larger ocean basin (marine sediments) to the restricted continental basin seen today (fluvial sediments). This insight improves our understanding of Coast Range development, forearc migration, and Cascade magmatism as it is recorded in the stratigraphy of the Portland and Tualatin basins. Transpressional oblique-slip faulting continues to play a role in deforming the region as the forearc undergoes clockwise rotation and northward migration, creating evident hazard for the Portland metropolitan and surrounding areas.

\section{ACKNOWLEDGMENTS}

Educational software licenses were provided by Esri ${ }^{\top M}$ (desktop.arcgis.com/en/). Kingdom ${ }^{\text {TM }}$ (https://ihsmarkit.com/products (kingdom-seismic-geological-interpretation-software.html), and Petrosys Pty Ltd (petrosys.com.au). This research was supported by the Department of Energy's Office of Energy Efficiency and Renewable Energy (EERE) office through the Portland Deep Direct-Use Thermal Energy Storage (DDU-TES) Feasibility Study, grant \#DE-EE0008104. Publication of this article in an open access journal was funded by the Portland State University ibrary's Open Access Fund.

\section{REFERENCES CITED}

Anderson, J.L., Tolan, T.L., and Wells, R.E., 2013, Strike-slip faults in the western Columbia River flood basalt province, Oregon and Washington, in Reidel, S.P., Camp, V.E., Ross, M.E., Wolff, J.A., Martin, B.S., Tolan, T.L., and Wells, R.E., eds., The Columbia River Flood Basalt Province: Geological Society of America Special Paper 497, p. 325-347, https://doi.org/10 $1130 / 2013.2497(13)$

Armentrout, J.M., 1983, Correlation of Cenozoic Stratigraphic Units of Western Oregon and Washington: Oregon Department of Geology and Mineral Industries Oil and Gas Investigations 7: Portland, Oregon, State of Oregon, Dept. of Geology and Mineral Industries, in cooperation with Washington Dept. of Natural Resources, Geology and Earth Resources Division, $93 \mathrm{p}$.

Bassett, D., and Watts, A.B., 2015, Gravity anomalies, crustal structure, and seismicity at subduction zones: 2 . Interrelationship between fore-arc structure and seismogenic behavior: Geochemistry, Geophysics, Geosystems, v. 16, p. 1541-1576, https://doi.org/10.1002/2014GC005685.

Beeson, M.H., and Tolan, T.L., 1990, The Columbia River Basalt Group in the Cascade Range: A Middle Miocene reference datum for structural analysis: Journal of Geophysical Research, v. 95, no. 19547, https://doi.org/10.1029 physical Research,
/JB095iB12p19547.

Beeson, M.H., Perttu, R., and Perttu, J., 1979, The origin of the Miocene basalts of coastal Oregon and Washington: An Miocene basalts of coastal Oregon and Washington: An
alternative hypothesis: Oregon Geology, v. 41, p. 159-166.

Beeson, M.H., Fecht, K.R., Reidel, S.P., and Tolan, T.L., 1985, Regional correlations within the Frenchman Springs Member of the Columbia River Basalt Group: New insights into the middle Miocene tectonics of northwestern Oregon: Oregon Geology, v. 47, p. 86-99, https://doi.org/10.1016/j .jvc.2009.09.003

Beeson, M.H., Tolan, T.L., and Anderson, J.L., 1989a, The Columbia River Basalt Group in western Oregon: Geologic structures and other factors that controlled flow emplacement patterns, in Reidel, S.P., and Hooper, P.R., eds., Volcanism and Tectonism in the Columbia River Flood-Basalt Province: Geological Society of America Special Paper 239, p. 223-246, https://doi org/10.1130/SPE239-p223.

Beeson, M.H., Tolan, T.L., and Madin, I.P., 1989b, Geologic map of the Lake Oswego quadrangle, Clackamas, Multnomah and Washington Counties, Oregon, Oregon Department of Geology and Mineral Industries Geological Map Series GMS-59, scale 1:24,000, 1 sheet.

Beeson, M.H., Tolan, T.L., and Madin, I.P., 1991, Geologic map of the Portland quadrangle, Clackamas, Multnomah, and Washington Counties, Oregon, and Clark County,
Washington: Oregon Department of Geology and Mineral Industries Geological Map Series GMS-75, scale 1:24,000, Industrite
1 sheet.

Bershaw, J., Cassel, E.J., Carlson, T.B., Streig, A.R., and Streck, M.J., 2019, Volcanic glass as a proxy for Cenozoic elevation and climate in the Cascade Mountains, Oregon, USA Journal of Volcanology and Geothermal Research, v. 381, P. M. a.J., Wells, R.E., Yelin, T.S., Madin, I.P, and Beeson, M.H., 1995, Tectonic setting of the Portland-Vancouver area, Oregon and Washington-Constraints from low-altitude aeromagnetic data: Geological Society of America Bulle tin, v. 107, p. 1051-1062, https://doi.org/10.1130/0016-7606 (1995) $107<1051$ TSOTPV $>2.3 . \mathrm{CO}, 2$.

Blakely, R.J., Wells, R.E., Tolan, T.L., Beeson, M.H., Trehu, A.M., and Liberty, L.M., 2000, New aeromagnetic data reveal large strike-slip (?) faults in the Northern Willamette Valley, Oregon: Bulletin of the Geological Society of America, v. 112, p. 1225-1233, https://doi.org/10.1130/0016-7606(2000)112

Blakely, R.J., Wells, R.E., Weaver, C.S., and Johnson, S.Y., 2002, Location, structure, and seismicity of the Seattle fault zone, Washington: Evidence from aeromagnetic anomalies, geologic mapping, and seismic-reflection data: Geological Society of America Bulletin, v. 114, p. 169-177, https://dol .org/10.1130/0016-7606(2002)114<0169:LSASOT>2.0.CO;2.

Blakely, R.J., Beeson, M.H., Cruikshank, K., Wells, R.E., Johnson, A., and Walsh, K., 2004, Gravity study through the Tualatin Mountains, Oregon: Understanding crustal structure and earthquake hazards in the Portland urban area: Bulletin of the Seismological Society of America, v. 94, p. 1402-1409, https://doi.org/10.1785/012003045.

Bodmer, M., Toomey, D.R., Roering, J.J., and Karlstrom, L., 2019, Asthenospheric buoyancy and the origin of high-relief topography along the Cascadia forearc: Earth and Planetary Science Letters, v. 531_https://doi.org/10.1016/j.epsl.2019.115965.

Brandon, M.T., Roden-Tice, M.K., and Garver, J.I., 1998, Late Cenozoic exhumation of the Cascadia accretionary wedge in the Olympic Mountains, northwest Washington state: Geological Society of America Bulletin, v. 110, no. 8, p. 985-1009, https://doi.org/10.1130/0016-7606(1998)110<0985:LCEOTC>2 .3.CO;2.

Burns, E.R., Morgan, D.S., Peavler, R.S., and Kahle, S.C., 2011 Three-Dimensional Model of the Geologic Framework for the Columbia Plateau Regional Aquifer System, Idaho, Oregon, and Washington: U.S. Geological Survey Scientific Investigations Report 2010-5246, 44 p., http://pubs.usgs.gov /sir/2010/5246, https://doi.org/10.3133/sir20105246.

Calvert, A.J., Preston, L.A., and Farahbod, A.M., 2011, Sedimentary underplating at the Cascadia mantle-wedge corner revealed by seismic imaging: Nature Geoscience, v. 4, no. 8 , p. 545-548, https://doi.org/10.1038/ngeo 1195 .

Conrey, R.M., Sherrod, D.R., Uto, K., and Uchiumi, S., 1996, Potassium-argon ages from Mount Hood area of $\mathrm{Cascad}$ Range, Northern Oregon: Isochron-West, v. 63, p. 10-20.

Dielforder, A., Hetzel, R., and Oncken, O., 2020, Megathrust shear force controls mountain height at convergent plate margins: Nature, v. 582, no. 7811 , p. 225-229, https://doi.org/10.1038 /s41586-020-2340-7.

Dinterman, P., and Duval, A., 2009, Preliminary geologic map of the Buxton $7.5^{\prime}$ quadrangle, Washington County, Oregon: 
U.S. Geological Survey Open-File Report 2009-1186, scale 1:24,000, 1 sheet, http://pubs.usgs.gov/of/2009/1186/.

Duncan, R.A., 1982, A captured island chain in the coast range of Oregon and Washington: Journal of Geophysical Research. Solld Earh, V. 87, P. 827-837.

Engebretson, D.C., and Kirby, S.H., 1995, Localized intraslab earthquakes and associated forearc basin subsidence in the Juan de Fuca subduction zone: subsidence mechanisms an earthquake hazard implications. Eos (Transactions, Amercan Geophysical Union), Supplement Fall Abstracts, p. 85.

Motions Between Oceanic and Continental Plates in the
Matich Motions Between Oceanic and Continental Plates in the
Pacific Basin: Geological Society of America Special Paper Pacific Basin: Geological Society of America
206, 60 p., https://doi.org/10.1130/SPE206-p1.

Evarts, R.C., O'Connor, J.E., Wells, R.E., and Madin, I.P., 2009 The Portland basin: A (big) river runs through it: GSA Today, v. 19, p. 4-10, https://doi.org/10.1130/GSATG58A.

Evarts, R.C., Conrey, R.M., Fleck, R.J., and Hagstrum, J.T., 2010, The Boring Volcanic Field of the Portland-Vancouver area Oregon and Washington: Tectonically anomalous forearc volcanism in an urban setting, in O'Connor, J.E., Dorsey, R.J., and Madin, I.P., eds., Volcanoes to Vineyards: Geologic Field Trips through the Dynamic Landscape of the Pacific Northwest: Geological Society of America Field Guide 15, p. 253-270, https://doi.org/10.1130/2009.fld015(13).

Flemings, P.B., and Jordan, T.E., 1990, Stratigraphic modeling of foreland basins: Interpreting thrust deformation an lithosphere rheology: Geology, v. 18, p. 430-434, https:/ doi.org/10.1130/0091-7613(1990)018<0430:SMOFBI>2.3.CO;

Frankel, A., Wirth, E., Marafi, N., Vidale, J., and Stephenson, W. 2018, Broadband synthetic seismograms for magnitude earthquakes on the Cascadia megathrust based on 3D sim ulations and stochastic synthetics (Part 1)-Methodology and overall results: Bulletin of the Seismological Society of America, v. 108, p. 2347-2369, https://doi.org/10.1785 10120180034.

Givler, R., Witter, R., Madin, I., and Amos, C., 2009, Paleoseismology of the Mount Angel fault in the Willamette Valle Oregon: Collaborative research with William Lettis \& Associates, Inc. and the Oregon Department of Geology and Mineral Industries: U.S. Geological Survey National Earthquake Hazards Reduction Program, $51 \mathrm{p}$

He, P., Wen, Y., Chen, Y., Xu, C., and Ding, K., 2020, Coseismic rup ture geometry and slip rupture process during the $2018 \mathrm{Mw}$ 7.1 Anchorage, south-central Alaska earthquake: Intraplat normal faulting by slab tear constrained by geodetic an teleseismic data: Earth and Space Science, v. 7, https://do .org/10.1029/2019EA000924.

Heller, P.L., Angevine, C.L., Winslow, N.S., and Paola, C., 1988, Two-phase stratigraphic model of foreland-basin sequences: Geology, v. 16, p. 501-504, https://doi.org/10.1130/0091-7613 (1988)016<0501:TPSMOF>2.3.CO;2.

Horst, A., Streig, A.R., Wells, R.E., and Guilderson, T., 2019, Seismic source characterization of faults in the Portland and Tualatin basins and a paleoseismic study of the Gales Creek Fault, OR: Geological Society of America Abstracts with Programs, v. 51, no. 4, https://doi.org/10.1130/abs/2019CD $-329221$.

Horst, A.E., Streig, A.R., Wells, R.E., and Bershaw, J., 2020 Multiple Holocene earthquakes on the Gales Creek Fault, northwest Oregon Fore-arc: Bulletin of the Seismological
Society of America, v. 111, p. 476-489, https://doi.org/10 .1785/0120190291.

Ingersoll, R.V., 1978, Petrofacies and petrologic evolution of the late Cretaceous fore-arc basin, northern and central California: The Journal of Geology, v. 86, p. 335-352, https:// doi.org/10.1086/649695.

Johnson, S.Y., Potter, C.J., and Armentrout, J.M., 1994, Origin and evolution of the Seattle fault and Seattle basin, Washington: Geology, v. 22, p. 71-74, https://doi.org/10.1130/0091 (1)

Kao, $H$. Wang, K Chen, R.Y. Wada, I. He, J, and Malone, S.D. 2008, Identifying the rupture plane of the 2001 Nisqually, Washington, earthquake: Bulletin of the Seismological Society of America, v. 98, no. 3, p. 1546-1558, https://doi.org/10 $.1785 / 0120070160$.

Letouzey, J., Werner, P., and Marty, A., 1990, Fault reactivation and structural inversion. Backarc and intraplate compressive deformations. Example of the eastern Sunda shelf (Indonesia): Tectonophysics, v. 183, p. 341-362, https://doi .org/10.1016/0040-1951(90)90425-8,

Liberty, L.M., 2002, Procurement and reprocessing of an industry marine seismic reflection profile from the Columbia River, Oregon and Washington: U.S. Geological Survey National Earthquake Hazards Reduction Program (NEHRP) Report, $14 \mathrm{p}$.

berty, L.M., Hemphill-Haley, M.A., and Madin, I.P., 2003, The Portland Hills Fault: Uncovering a hidden fault in Portland Oregon using high-resolution geophysical methods: Tec tonophysics, v. 368, p. 89-103, https://doi.org/10.1016/S0040 -1951(03)00152-5.

Ma, L., Madin, I.P., Duplantis, S., and Williams, K.J., 2012, Lidarbased surficial geologic map and database of the greater Portland, Oregon, area, Clackamas, Columbia, Marion, Multnomah, Washington, and Yamhill Counties, Oregon, and Clark County, Washington: State of Oregon Department of Geology of Mineral Industries Open-File Report 0-12-02, scale 1:63,360, 1 sheet, $30 \mathrm{p}$. text.

Madin, I.P., 1990, Earthquake-Hazard Geology Maps of the Portland Metropolitan area, Oregon: Text and Map Explanation: State of Oregon Department of Geology and Mineral Indus tries Open-File Report 0-90-2, scale 1:24,000, 8 sheets, 21 p. text.

Matthews, K.J., Maloney, K.T., Zahirovic, S., Williams, S.E., Seton M., and Mueller, R.D., 2016, Global plate boundary evolution and kinematics since the late Paleozoic: Global and Planetary Change, v. 146, p. 226-250, https://doi.org/10.1016/j gloplacha.2016.10.002.

McCaffrey, R., King, R.W., Payne, S.J., and Lancaster, M., 2013, Active tectonics of northwestern U.S. inferred from GPS derived surface velocities: Journal of Geophysical Research Solid Earth, v. 118, p. 709-723, https://doi.org/10.1029 /2012JB009473.

McCaffrey, R., King, R.W., Wells, R.E., Lancaster, M., and Miller, M.M., 2016, Contemporary deformation in the Yakima fold and thrust belt estimated with GPS: Geophysical Journal International, v. 207, p. 1-11, https://doi.org/10.1093/gii lggw252.

McCaffrey, R., Qamar, A.I., King, R.W., Wells, R.E., Khazaradze, G., Williams, C.A., Stevens, C.W., Vollick, J.J., and Zwick, P.C. 2007, Fault locking, block rotation and crustal deformation in the Pacific Northwest: Geophysical Journal International v. 169, p. 1315-1340, https://doi.org/10.1111/j.1365-246X.2007 .03371.x.

McKeel D.R. 1984, Biostratigraphy of Exploratory Wells in Western Coos, Douglas, and Lane Counties, Oregon: State of Oregon Department of Geology and Mineral Industries Oil and Gas Investigation 11, $24 \mathrm{p}$.

McPhee, D.K., Langenheim, V.E., Wells, R.E., and Blakely, R.J., 2014, Tectonic evolution of the Tualatin basin, northwest Oregon, as revealed by inversion of gravity data: Geosphere v. 10, p. 264-275, https://doi.org/10.1130/GES00929.1.

列on, A.R., Personius, S.F., Sherrod, B.L., Kelsey, H.M., Johnson, S.Y., Bradley, L.A., and Wells, R.E., 2014, Diverse rupture modes for surface-deforming upper plate earthquakes in the southern Puget Lowland of Washington State: Geosphere, v. 10, no. 4, p. 769-796, https://doi.org/10.1130/GES00967.1. wton, V.C., 1969, Subsurface Geology of the Lower Columbia and Willamette Basins, Oregon: State of Oregon Department of Geology and Mineral Industries Oil and Gas Investigations 2, $130 \mathrm{p}$.

Niedzielski, T., Jurecka, M., and Migon, P., 2016, Semi-empirical oceanic depth-age relationship inferred from bathymetric curve: Pure and Applied Geophysics, v. 173, p. 1829-1840, https://doi.org/10.1007/s00024-015-1204-9.

Niem, A.L., and Niem, W.A., 1985, Geologic Map of the Asto ria Basin, Clatsop and Northernmost Tillamook Counties, Northwest Oregon: State of Oregon Department of Geology and Mineral Industries Oil and Gas Investigations 14, scale 1:100,000, 1 sheet

Niem, A.R., MacLeod, N.S., Snavely, P.D., Huggins, D., Fortier, J.D., Meyer, J.H., Seeling, A.F, and Niem, W.A., 1992a Onshore-offshore Geologic Cross Section, Northern Oregon Coast Range To Continental Slope: State of Oregon Department of Geology and Mineral Industries Special Paper 26, scale 1:100,000, 1 sheet, $10 \mathrm{p}$. text.

Niem, W.A., Niem, A.R., and Snavely, P.D., 1992b, Early and Mid-Tertiary oceanic realm and continental margin-wesern Washington-Oregon coastal sequence, in Burchfiel, B.C. Lipman, P.W., and Zoback, M.L., eds., The Cordilleran Orogen: Conterminous U.S.: Geological Society of America, The Geology of North America, v. G-3, p. 265-270.

Oregon Department of Geology and Mineral Industries, 2012, Western Oregon Seismic Reflection Data Imagery: Open-File Report 0-12-04, 54 oversize sheets as digital files, https:/ www.oregongeology.org/pubs/ofr/p-O-12-04.htm.

Parker, M.J., 1990, The Oligocene and Miocene Geology of the Tillamook Embayment, Tillamook County, Northwest Oregon [M.S. thesis]: Corvallis, Oregon, Oregon State University, $275 \mathrm{p}$.

Popowski, T.A., 1996, Geology, structure, and tectonic history of the Tualatin Basin, northwestern Oregon [M.S. thesis] Corvallis, Oregon, Oregon State University, $142 \mathrm{p}$.

Rau, W.W., and Johnson, S.Y., 1999, Well stratigraphy and correlations: Western Washington and northwestern Oregon: U.S. Geological Survey Geologic Investigations Series, v. I-2621, $36 \mathrm{p}$.

Redwine, J., Klinger, R.E., Piety, L.A., Wells, R.E., Sherrod, B.L, Howe, J.C., Levinson, R., Hornsby, K., and Niem, A., 2017, Quaternary activity on the Gales Creek Fault, northwest Oregon: Geological Society of America Abstracts with Programs, v. 49, no. 6, https://doi.org/10.1130/abs/2017AM -306019 . 
Reidel, S.P., Camp, V.E., Tolan, T.L., and Martin, B.S., 2013, The Columbia River flood basalt province: Stratigraphy, areal extent, volume, and physical volcanology, in Reidel, S.P. Camp, V.E., Ross, M.E., Wolf, J.A., Martin, B.S., Tolan, T.L. and Wells, R.E., eds., The Columbia River Flood Basal Province: Geological Society of America Special Paper 497

Reidel, S.P., Fecht, K.R., Hagood, M.C., and Tolan, T.L., 1989, The geologic evolution of the central Columbia Plateau, in Reide S.P., and Hooper, P.R., eds., Volcanism and Tectonism in the Columbia River Flood-Basalt Province. Geological Society of America Special Paper 239, p. 247-264, https://doi.org /10.1130/SPE239-p247.

Reiners, P.W., Ehlers, T.A., Garver, J.I., Mitchell, S.G., Montgom ery, D.R., Vance, J.A., and Nicolescu, S., 2002, Late Miocene exhumation and uplift of the Washington Cascade Range Geology, v. 30, p. 767-770, https://doi.org/10.1130/0091-7613 (2002)030<0767:LMEAUO>2.0.CO;

Retallack, G.J., Orr, W.N., Prothero, D.R., Duncan, R.A., Kester, P.R., and Ambers, C.P., 2004, Eocene-Oligocene extinction and paleoclimate change near Eugene, Oregon: Geologica Society of America Bulletin, v. 116, p. 817-839, https://do .org/10.1130/B25281.1.

Roe, W.P., and Madin, I.P., 2013, 3D Geology and Shear-Wave Velocity Models of the Portland, Oregon, Metropolitan Area: Oregon Department of Geology and Mineral Industrie Open-File Report 0-13-12, $48 \mathrm{p}$.

Rogers, G.C., 2002, The role of phase changes in the deveopment of forearc basins, in The Cascadia Subduction Zone and Related Subduction Systems: Seismic Structure, Intraslab Earthquakes and Processes, and Earthquake Hazards: U.S. Geological Survey Open-File Report 02-328, p. 147

Schmandt, B., and Humphreys, E., 2011, Seismically imaged relict slab from the $55 \mathrm{Ma}$ Siletzia accretion to the northwest United States: Geology, v. 39, p. 175-178, https://do .org/10.1130/G31558.

Schwab, F.L., 1976, Modern and ancient sedimentary basins: Comparative accumulation rates: Geology, v. 4, p. 723-727, https://doi.org/10.1130/0091-7613(1976)4<723:MAASBC>2 $.0 . \mathrm{CO} ; 2$

Severinghaus, J., and Atwater, T., 1990, Cenozoic geometry and thermal state of the subducting slabs beneath western North America, in Wemicke, B.P., ed., Basin and Range Extensional Tectonics near the Latitude of Las Vegas, Nevada: Geological Society of America Memoir 176, 22 p. https://doi.org/10.1130/MEM176-p1.

Sherrod, B.L., Brocher, T.M., Weaver, C.S., Bucknam, R.C. Blakely, R.J., Kelsey, H.M., Nelson, A.R., and Haugerud, R., 2004, Holocene fault scarps near Tacoma, Washington, USA Geology, v. 32, p. 9-12, https://doi.org/10.1130/G19914.1. Sibson, R.H., 1985, A note on fault reactivation: Journal of Struc
tural Geology, v. 7, p. 751-754, https://doi.org/10.1016/0191 -8141(85)90150-6.

Sibson, R.H., Francois, R., and Poulsen, K.H., 1988, High-angle reverse faults, fluid-pressure cycling, and mesothermal gold-quartz deposits: Geology, v. 16, p. 551-555, https:// doi.org/10.1130/0091-7613(1988)016<0551:HARFFP >2.3.CO;2.

Snavely, P.D., MacLeod, N.S., and Wagner, H.C., 1968, Tholeiitic and alkalic basalts of the Eocene Siletz River Volcanics, Ore gon: American Journal of Science
Snavely, P.D., and Wagner, H.C., 1963, Tertiary Geologic History of Western Oregon and Washington: State of Washington Department of Conservation, $32 \mathrm{p}$.

Snavely, P.D., and Wells, R.E., 1991, Cenozoic Evolution of the Continental Margin of Oregon and Washington, in Earthquake Hazards in the Pacific Northwest of the United States United States Department of the Interior: Geological Survey Open-File Report 91-441-B, 34 p.

Snavely, P.D., and Wells, R.E., 1996, Cenozoic evolution of the continental margin of Oregon and Washington, in Assessing Earthquake Hazards and Reducing Risk in the Pacific Northwest: U.S. Geological Survey Professional Paper 1560, p. 161-182.

Snavely, P.D., Jr., MacLeod, N.S., and Wagner, H.C., 1973, Miocene tholeiitic basalts of coastal Oregon and Washington and their relations to coeval basalts of the Columbia Plateau: Geological Society of America Bulletin, v. 84, no. 2, p. 387-424, https://doi.org/10.1130/0016-7606(1973)84<387; $\mathrm{MTBOCO}>2.0 . \mathrm{CO} ; 2$

Snavely, P.D., Wells, R.E., and Minasian, D., 1993, The Cenozoic geology of the Oregon and Washington Coast Range, in Northwest Petroleum Association 9th Annual Field Trip Cenozoic Geology of Coastal Northwest Oregon: U.S. Geological Survey Open-File Report, $40 \mathrm{p}$.

Spitzer, R., White, R.S., Christie, P.A.F., and Team, I., 2008, Seismic characterization of basalt flows from the Faroes margin and the Faroe-Shetland basin: Geophysical Prospecting v. 56, p. 21-31.

Stanley, R.G., 1991, Geologic Basis for Petroleum Resource Assessment of Onshore Western Oregon and Washington (Province 72): U.S. Geological Survey Open-File Report 88-450X, $29 \mathrm{p}$.

Symons, N.P., and Crosson, R.S., 1997, Seismic velocity structure of the Puget Sound region from 3-D non-linear tomography: Geophysical Research Letters, v. 24, p. 2593-2596, https:// doi.org/10.1029/97GL52692.

ten Brink, U.S., Molzer, P.C., Fisher, M.A., Blakely, R.J., Bucknam, R.C., Parsons, T., Crosson, R.S., and Creager, K.C. 2002, Subsurface geometry and evolution of the Seattle Fault Zone and the Seattle Basin, Washington: Bulletin of the Seismological Society of America, v. 92, p. 1737-1753, https://doi.org/10.1785/0120010229.

Thomas, G.C., Crosson, R.S., Carver, D.L., and Yelen, T.S., 1996, The 25 March 1993 Scotts Mills, Oregon, earthquake and aftershock sequence: Spatial distribution, focal mechanisms, and the Mount Angel Fault: Bulletin of the Seismological Society of America, v. 86, p. 11

Tolan, T.L., and Beeson, M.H., 1984, Intracanyon flows of the Columbia River Basalt Group in the Lower Columbia River Gorge and their relationship to the Troutdale Formation: Bulletin of the Geological Society of America, v. 95, p. 463-477, https://doi.org /10.1130/0016-7606(1984)95<463:IFOTCR>2.0.CO;2.

Treasher, R.C., 1942, Geologic history of the Portland area: Department of Geology and Mineral Industries GMI Short Paper, no. 7, $17 \mathrm{p}$

Trehu, A.M., Asudeh, I., Brocher, T.M., Luetgert, J.H., Mooney, W.D., Nabelek, J.L., and Nakamura, Y., 1994, Crustal architecture of the Cascadia forearc: Science, v. 266, p. 237-243, https://doi.org/10.1126/science.266.5183.237.

Trimble, D.E., 1963, Geology of Portland, Oregon and adjacent areas: Geological Survey Bulletin, v. 1119, $247 \mathrm{p}$
USGS (U.S. Geological Survey), 2013, Columbia River Basalt Stratigraphy in the Pacific Northwest: https://or.water.usgs ov/projs_dir/crbg/data/index.html (accessed May 2019).

Waitt, R.B., 1985, Case for periodic, colossal jökulhlaups from Pleistocene glacial Lake Missoula: Geological Society of America Bulletin, v. 96, p. 1271-1286, https://doi.org/10.1130 10016-7606(1985)96<1271:CFPCJF>2.0.CO;2.

Wald, D.J. 1996, Slip history of the 1995 Kobe, Japan, earthquake determined from strong motion, teleseismic, and geodetic data: Journal of Physics of the Earth, v. 44, no. 5, p. 489-503, https://doi.org/10.4294/jpe 1952.44.489.

Walker, G.W., and MacLeod, N.S., 1991, Geologic map of Oregon: U.S. Geological Survey, scale 1:500,000, 2 sheets.

alsh, K., Peterson, G.L., Beeson, M.H., Wells, R.E., Fleck, R.J., Evarts, R.C., Duvall, A., Blakely, R.J., and Burns, S., 2011, A tunnel runs through it-An inside view of the Tualatin Mountains, Oregon: U.S. Geological Survey Scientific Investigations Map 3144, 1 sheet, https://doi.org/10.3133/sim3144. Waltham, D., Hall, R., Smyth, H.R., and Ebinger, C.J., 2008, Basin formation by volcanic arc loading, in Draut, A.E., Clift, P.D., and Scholl, D.W., eds., Formation and Applications of the Sedimentary Record in Arc Collision Zones: Geological Society of America Special Paper 436, p. 11-26, https://doi.org $/ 10.1130 / 2008.2436(02)$

Wells, R., Haugerud, R.A., Niem, A.R., Niem, W.A., Ma, L., Evarts, R.C., O'Connor, J.E., Madin, I.P., Sherrod, D.R., Beeson, M.H. Tolan, T.L., Wheeler, K.L., Hanson, W.B., and Sawlan, M.G. 2020a, Geologic map of the greater Portland metropolitan area and surrounding region, Oregon and Washington: U.S. Geological Survey Scientific Investigations Map 3443, scale 1:63,360, 2 sheets, 55 p. text, https://doi.org/10.3133 $1 \operatorname{sim} 3443$

Wells, R.E., Bukry, D., Friedman, R., Pyle, D., Duncan, R., Haeussler, P., and Wooden, J., 2014, Geologic history of Siletzia, a large igneous province in the Oregon and Washington Coas Range: Correlation to the geomagnetic polarity time scale and implications for a long-lived Yellowstone hotspot: Geosphere, v. 10, p. 692-719, https://doi.org/10.1130/GES01018.

Wells, R.E., Blakely, R.J., and Bemis, S., 2020b, Northward migration of the Oregon forearc on the Gales Creek fault: Geosphere, v. 16, p. 660-684, https://doi.org/10.1130 /GES02177.1.

Wells, R.E., and McCaffrey, R., 2013, Steady rotation of the Cascade arc: Geology, v. 41, p. 1027-1030, https://doi.org/10 $.1130 / \mathrm{G} 34514.1$.

Wells, R.E., Engebretson, D.C., Snavely, P.D., and Coe, R.S., 1984, Cenozoic plate motions and the volcano-tectonic evolution of western Oregon and Washington: Tectonics, v. 3, p. 275294, https://doi.org/10.1029/TC003i002p00275

Wells, R.E., Snavely, P.D., MacLeod, N.S., Kelly, M.M., and Parker, M.J., 1994, Geologic map of the Tillamook Highlands, northwest Oregon Coast Range: U.S. Geological Survey Open-File Report 94-0021, scale 1:62,500, 2 sheets, 24 p. text, https:// doi.org/10.3133/ofr9421.

Wells, R.E., Weaver, C.S., and Blakely, R.J., 1998, Fore-arc migration in Cascadia and its neotectonic significance: Geology, v. 26, p. 759-762, https://doi.org/10.1130/0091-7613(1998)026 $<0759:$ FAMICA $>2.3 . C O ; 2$.

Werner, K.S., 1990, I, Direction of maximum horizontal compression in western Oregon determined by borehole breakouts: II, Structure and tectonics of the northern Willamette Valley, 
Oregon [M.S. thesis]: Corvallis, Oregon, Oregon State University, $156 \mathrm{p}$.

West, M.E., Bender, A., Gardine, M., Gardine, L., Gately, K., Hae ussler, P., Hassan, W., Meyer, F., Richards, C., Ruppert, N. and Tape, C., 2020, The 30 November $2018 \mathrm{Mw} 7.1$ Anchorage earthquake: Seismological Research Letters, v. 91, no. 1 p. 66-84, https://doi.org/10.1785/0220190176.

Wilson, D., 2000, Provenance of the Hillsboro Formation: Implcations for the structural evolution and fluvial events in the Tualatin Basin, northwest Oregon: Journal of Sedimentary Research, v. 70, p. 117-126, https://doi.org/10.1306/2DC40903 -0 E47-11D7-8643000102C1865D.

Wilson, D.C., 1997, Post-Middle Miocene Geologic History of the Tualatin Basin, Oregon with Hydrogeologic Implications [Ph.D. dissertation]: Portland, Oregon, Portland State University, $310 \mathrm{p}$.
Wilson, D.C., 1998, Post-middle Miocene geologic evolution of the Tualatin basin, Oregon: Oregon Geology, v. 60 p. 99-116.

Wilson, D.S., 2002, The Juan de Fuca plate and slab: Isochron structure and Cenozoic plate motions, in Kirby, S., Wang, K., and Dunlop, S., eds., The Cascadia Subduction Zone and Related Subduction Systems: U.S. Geological Survey Open-File Report 02-328, p. 9-12.

Wirth, E.A., Vidale, J.E., Frankel, A.D., Pratt, T.L., Marafi, N.A. Thompson, M., and Stephenson, W.J., 2019, Sourcedependent amplification of earthquake ground motions in deep sedimentary basins: Geohysical Re d. 46, p. 6443-6450, V. 46, p. 6443-6450, https://doi.org/10.1029/2019GL082474. 2001, The Porland Hils fault: An earthquake generator or
Yeats, R.S., Graven, E.P., Werner, K.S., Goldfinger, C., and Popowski, T., 1991, Tectonics of the Willamette Valley, Oregon, in Earthquake Hazards in the Pacific Northwest of the United States: U.S. Geological Survey Open-File Report 91-441-P, 47 p.

Yeats, R.S., Graven, E.P., Werner, K.S., Goldfinger, C., and Popowski, T.A., 1996, Tectonics of the Willamette Valley, Oregon, in Assessing Earthquake Hazards and Reducing Risk in the Pacific Northwest Volume 1: U.S. Geological Survey Professional Paper 1560, p. 183-222.

Yelin, T.S., and Patton, H.J., 1991, Seismotectonics of the Portland, Oregon, region: Bulletin of the Seismological Society of America, v. 81, p. 109-130.

Zak, l., and Freund, R., 1981, Asymmetry and basin migration in the Dead Sea Rift, in Freund, R., and Garfunkel, Z., The Dead Sea Rift: Tectonophysics, v. 80, no. 1-4, p. 27-38, https://doi .org/10.1016/0040-1951(81)90140-2. 